\title{
ФОРМЫ НАХОЖДЕНИЯ ГЕРМАНИЯ И ВОЛЬФРАМА В ГЕРМАНИЙ-УГОЛЬНОМ МЕСТОРОЖДЕНИИ СПЕЦУГЛИ (ДАЛЬНИЙ ВОСТОК)
}

\author{
Арбузов Сергей Иванович1, \\ siarbuzov@mail.ru
}

\section{Ильенок Сергей Сергеевич 1 ,} ilenokss@tpu.ru

\author{
Чекрыжов Игорь Юрьевич2, \\ chekr2004@mail.ru \\ 1 Национальный исследовательский Томский политехнический университет, \\ Россия, 634050, г. Томск, пр. Ленина, 30. \\ 2 Дальневосточный геологический институт ДВО РАН, \\ Россия, 690022, г. Владивосток, пр. 100-летия Владивостоку, 159.
}

\begin{abstract}
Актуальность исследования обусловлена необходимостью оценки форм нахождения германия и других попутных элементов примесей в германий-угольных месторождениях.

Цель: изучить формы нахождения германия и вольфррама в металлоносных уәлях месторождения Спецугли (Дальний Восток). объекты: угли и углистые алевролиты германий-угольного месторождения.

Методы: корреляционный анализ, изучение группового состава бурого угля, масс-спектрометрия с индуктивно связанной плазмой, инструментальный нейтронно-активационный анализ, сканирующая электронная микроскопия.

Результаты. Изучены основные форммы нахождения германия и вольфррама в углях месторождения Спецугли. В высокогерманиеносных уелях месторождения Спецуели германий характеризуется разнообразными фоормами нахождения. Наряду с преобладающей германий-органической формой, значительную роль играют минеральные фразы. Установлено, что значение минеральных форм нахождения в кониентрировании германия в высокогерманиеносных углях значительно выше, чем предполагалось ранее. $B$ угольных пластах, особенно отчетливо вблизи коры выветривания по грейзенизированным гранитам, широко распространены различные германийсодержащие минеральные фразы микронной и нанометровой размерности. В углях выявлены алюмосиликатная (силикатная) форма германия, разнообразные железистые (гидрогётит, гётит, ярозит) и полиминеральные фразы. Алюмосиликатная (силикатная) фраза представлена пленкоподобными агрегатами, содержащими 0,15-0,4 \% германия. В железистых минеральных агрегатах содержится от 0,1 до 6,2 \% германия. Аномальные содержания германия совместно с вольфррамом и мышьяком установлены в железомарганцевых корках - продуктах выветривания грейзенизированных гранитов фундамента, ссрормировавшихся в условиях палеоболота. Наличие вторичных минеральных фаз германия в углях, развитых по диагенетическим минералам, позволяет предполагать, что фрормирование германиевой минерализации в месторождении может быть полихронным и не ограничивается торффяной стадией. Для вольфррама выявлена преимущественно органическая форма нахождения. Роль минеральных форм вольфррама в общем его балансе в углях месторождения Спецугли незначительна. В изученных 9 пробах угля выявлено всего 1 зерно шеелита. Вблизи коры выветривания вольфррам в углях также встречается в качестве примеси в железомарганцевых «корках». Эти данные согласуются с результатами анализа распределения вольфррама по фрракциям группового состава. После извлечения гумусовых кислот в щелочную вы Ітяжку переходит в среднем 99 \% вольфррама. При этом в щелочной вытяжке около половины его связано с гуминовыми кислотами, а остальная часть - с низкомолекулярными органическими кислотами.
\end{abstract}

\section{Ключевые слова:}

Германий-угольное месторождение, уголь, фоормы нахождения, германий, вольфррам, органические формы, микроминеральные фразы.

\section{Введение}

Формы нахождения химических элементов являются важным показателем условий образования углей, природы формирования в них геохимических аномалий, важным фактором, определяющим рентабельность и технологию извлечения ценных элементовпримесей из углей и углеотходов. Проблема заключается не только в сложности распознавания отдельных форм нахождения элементов, но и в необходимости оценки соотношения (баланса) разных форм в конкретных типах угля.

Месторождение Спецугли - одно из крупнейших германий-угольных месторождений мира $[1,2]$. Сoгласно опубликованным данным, в результате промышленной отработки германиеносных углей месторождения Спецугли в 2017 г. по традиционной техно- логии, включающей стадию получения обогащенной металлом золы уноса, коэффициент извлечения составил 28,74 \% [3]. Соответственно, технологические потери германия при сжигании угля составили $71,26 \%$, в том числе со шлаками $-67,13 \%$. Такие большие потери при используемой технологии получения промышленного концентрата помимо других причин могут быть обусловлены недостоверной оценкой баланса минеральной и органической форм нахождения германия, которые во многом определяют подвижность германия в процессе сжигания угля и концентрирование его в золе уноса. Современная аналитическая техника высокого разрешения позволяет более достоверно оценить соотношение минеральных и неминеральных форм нахождения германия и других сопутствующих элементов в углях. 
Многочисленными исследованиями доказано и традиционно считается, что германий в углях сконцентрирован в основном в органическом веществе. Доля неорганических форм незначительна, в основном в пределах 2-3 \% [4], и в целом не превышает 10-20\% [5]. Современные данные показывают, что в германиеносных бурых углях соотношение органической и минеральной форм германия может существенно варьировать. Согласно результатам исследований германийугольного месторождения Спецугли [6], сделан вывод, что с минеральной фазой может быть связано до 25-30 \% германия в месторождении. При этом, не менее $60 \%$ германия в нем связано с мобильным органическим веществом, в том числе от 25 до 60 \% приходится на комплексные соединения германия с гуминовыми кислотами, и 8-39 \% связано с низкомолекулярной фрак- цией органического вещества, не осаждаемой кислотами. В.И. Вялов и др. [7], используя методику ICP MS с лазерной абляцией, впервые наглядно показали, что основным носителем германия в углях этого месторождения является $\Delta$-витринит.

Вольфрам является традиционным спутником германия в германий-угольных месторождениях $[8,1]$. Формы его нахождения в углях в целом исследованы в существенно меньшей степени, чем формы германия, а в месторождении Спецугли не изучены совсем.

Цель данной работы - выяснение основных форм нахождения германия и сопутствующего вольфрама с использованием современных аналитических методов и высокоразрешающей сканирующей электронной микроскопии и оценка соотношения этих форм в наиболее обогащенных германием углях месторождения Спецугли.

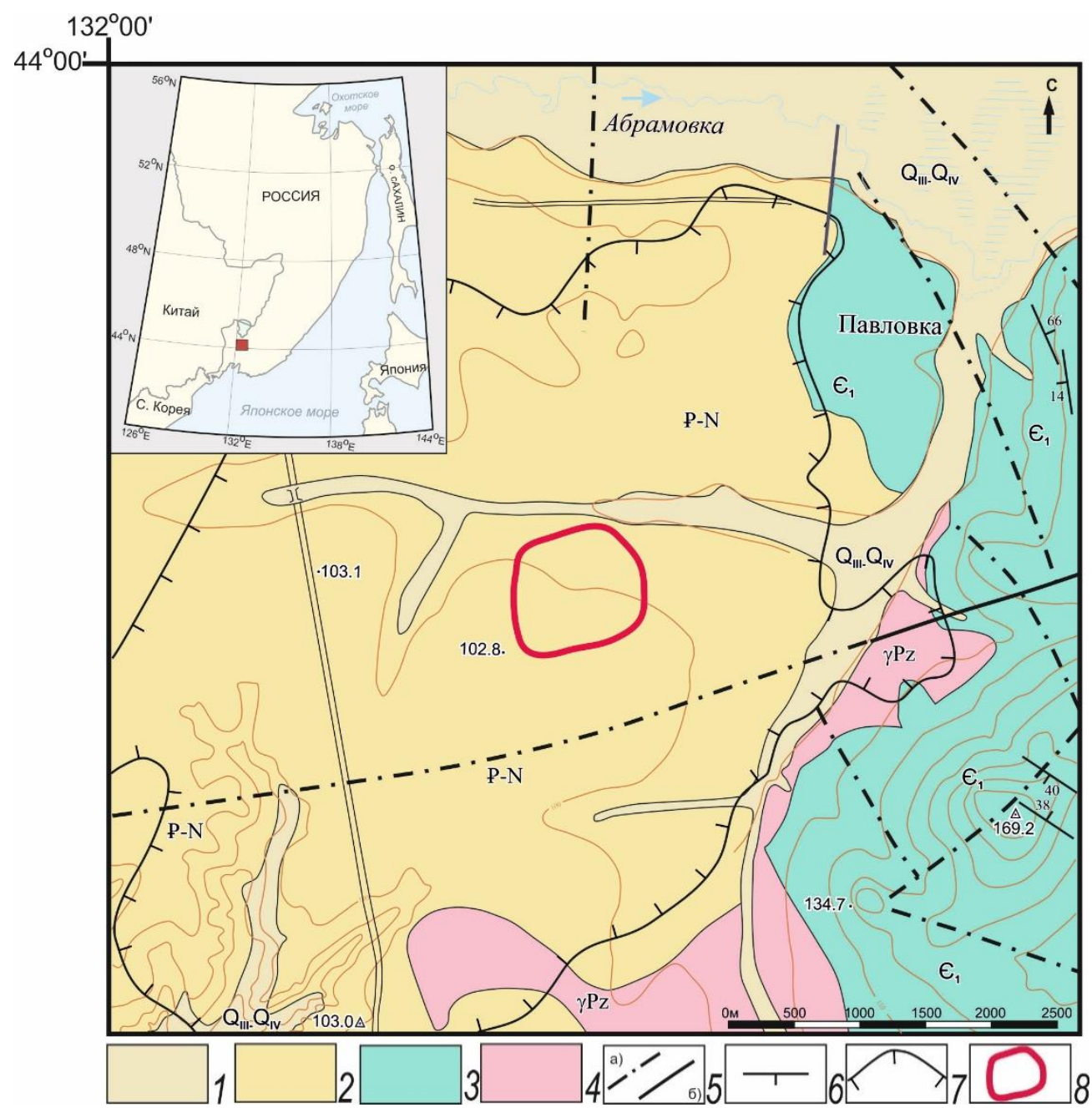

Рис. 1. Схема размещения месторождения Спеиугли на территории Дальнего Востока и геологическая карта района расположения месторождения: 1 - четвертичные аллювиальные отложения (пески, галечники); 2 - палеоген-неогеновые песчано-галечниковые (неоген) и угленосные отложения (песчаники, алевролиты, аргиллиты и угли) (палеоген); 3 - позднекембрийские отложения (сланиы серииитовые, квари-серицитовые, углеродистые, алевролиты, линзы известняков); 4 - палеозойские граниты; 5 - разломы: а) предполагаемые, б) установленные; 6 - элементы залегания; 7 - граница угленосных отложений Павловской впадины; 8 - месторождение германия Спеиугли

Fig. 1. Scheme of location of the Spetsugli deposit in Russian Far East and geological map of the deposit location area: 1 Quaternary alluvial sediments (sand, gravel); 2 - Paleogene-Neogene sand-gravel (Neogene) and coal sediments (sandstone, siltstone, argillite, and coal) (Paleogene); 3 - Late Cambrian sediments (sericitic, quarz-sericitic, and carboniferous shales, siltstone, limestone lens); 4 -Paleozoic granites; 5 -faults: a) supposed, 6) determined; 6 strike and dip; 7 - boundary of coal-bearing deposits of the Pavlovsk depression; 8 - germanium deposit Spetsugli 


\section{Объекты исследования}

Месторождение германия Спецугли расположено на юго-западной окраине Ханкайского массива, в восточной части Павловской впадины (рис. 1), в одной из депрессий, составляющих Павловское угольное поле [9]. Особенности геологического строения месторождения германия Спецугли в пределах Павловского буроугольного месторождения достаточно детально описаны в многочисленных работах $[1,7,10,11]$.

Высокие содержания германия приурочены к локальному поднятию гранитного фундамента с примыкающими и перекрывающими его четырьмя рудоносными угольными пластами (I, II нижний, II верхний, III нижний) павловской свиты эоценолигоценового возраста с общей мощностью угленосных отложений до 100 м. Угленосные отложения представлены серыми и коричневато-серыми слаболитифицированными аргиллитами, алевролитами и песчаниками с линзами и горизонтами галечников.

Угли месторождения бурые подгруппы 2БВ, среднезольные (16-18 \%), малосернистые (0,4-0,5 \%), с теплотой сгорания «рабочего» топлива 12,0-12,5 МДж/кг [10]. Микроструктура угля фрагментарная, аттритовофрагментарная. В исходном растительном материале углей преобладают остатки стеблевой древесины, в меньшем количестве коровые ткани и остатки листовой паренхимы. Мацеральный состав характеризуется высоким содержанием витринита от 80 до $99 \%$, представленным главным образом аттритом и фрагментами структурного и слабо структурированного витринита, остатками древесины, листовой паренхимы и коровой ткани [3]. Угленосная толща с размывом и угловым несогласием перекрыта неогеновыми рыхлыми аллювиальными отложениями. Выше залегает горизонт глин четвертичного возраста

Месторождение германия представляет собой субизометричный по контуру блок площадью около 1

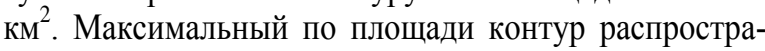
нения промышленной германиеносности был установлен в нижнем (I) наиболее мощном угольном пласте и подстилающих его углистых аргиллитах. Контур уменьшается к верхним пластам II и III групп, образуя «этажное» строение месторождения. В вертикальном разрезе для рудоносных пластов при общем уменьшении снизу вверх промышленной значимости каждого из них в этом же направлении возрастают средние содержания германия в пластах [10]. Согласно другим данным $[3,11]$, соотношение обратное: вверх по разрезу среднее содержание в пластах снижается. Кроме германия в угольных пластах установлены высокие концентрации вольфрама, бериллия и сурьмы.

Для изучения форм нахождения германия и вольфрама в настоящей работе опробованы маломощные пласты верхней группы (рис. 2).

Опробование выполнено в пределах угледобывающего разреза как в контуре промышленного германиевого оруденения, так и вне его. Всего отобрано 36 проб угля и 28 проб углевмещающих пород. Все пробы исследованы на германий и комплекс элементов- спутников. Две пробы угля с высокими содержаниями использованы для анализа группового состава и 9 проб - для электронно-микроскопического анализа (табл. 1).

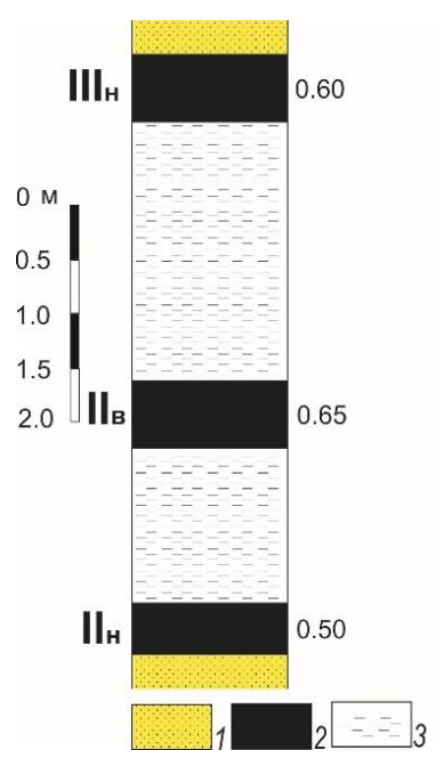

Pис. 2. Схема размещения опробованных угольных пластов в угленосном разрезе: 1 - песчаник, 2 уголь, 3 - алевролит

Fig. 2. Scheme of location of the sampled coal seams in the coal-bearing section: 1 - sandsone, 2 - coal, 3 siltstone

Таблица 1. Характеристика проб угля месторождения Спеиугли для исследования группового состава и электронно-микроскопических исследований

Table 1. Characteristics of the coal samples from the Spetsugli deposit for the research of the phase composition and electron-microscopic studies

\begin{tabular}{|c|c|c|c|c|c|}
\hline \multirow[t]{2}{*}{$\begin{array}{l}\text { Шифр } \\
\text { пробы } \\
\text { Sample } \\
\text { code }\end{array}$} & \multirow[t]{2}{*}{$\begin{array}{c}\text { Состав } \\
\text { пробы, } \\
\text { Sample } \\
\text { composition }\end{array}$} & \multirow[t]{2}{*}{$\begin{array}{c}\text { Угольный } \\
\text { пласт } \\
\text { Coal seam }\end{array}$} & \multirow[t]{2}{*}{$\begin{array}{l}\text { Золь- } \\
\text { ность } \\
\left(\mathrm{A}^{\mathrm{d}}\right), \% \\
\text { Ash, \% }\end{array}$} & \multicolumn{2}{|c|}{$\begin{array}{c}\text { Содержание } \\
\text { элементов, г/т } \\
\text { Element content, } \\
\text { ppm }\end{array}$} \\
\hline & & & & $\mathrm{Ge}$ & W \\
\hline СУ-56-18 & $\begin{array}{l}\text { Уголь бурый } \\
\text { Brown coal }\end{array}$ & $\begin{array}{l}\text { III нижний } \\
\text { III nizhny }\end{array}$ & 9,5 & 1600 & 563 \\
\hline Сy-103-19 & $\begin{array}{l}\text { Уголь бурый } \\
\text { Brown coal }\end{array}$ & $\begin{array}{l}\text { II нижний } \\
\text { II nizhny }\end{array}$ & 26,5 & 2540 & 417 \\
\hline СУ-6-18 & $\begin{array}{l}\text { Углистый } \\
\text { алевролит } \\
\text { Coal siltstone }\end{array}$ & $\begin{array}{l}\text { II нижний } \\
\text { II nizhny }\end{array}$ & 86,5 & 377 & 68 \\
\hline СУ-7-18 & $\begin{array}{l}\text { Углистый } \\
\text { алевролит } \\
\text { Coal siltstone } \\
\end{array}$ & $\begin{array}{l}\text { II нижний } \\
\text { II nizhny }\end{array}$ & 67,8 & 844 & 218 \\
\hline Сy-9-18 & $\begin{array}{l}\text { Угольное } \\
\text { включение } \\
\text { Coal inclu- } \\
\text { sion }\end{array}$ & $\begin{array}{c}\text { между I и } \\
\text { II пластом } \\
\text { between } \\
\text { seams } \\
\text { I and II }\end{array}$ & 10,9 & 5306 & 489 \\
\hline СУ-51-18 & $\begin{array}{l}\text { Уголь бурый } \\
\text { Brown coal }\end{array}$ & $\begin{array}{l}\text { II нижний } \\
\text { II nizhny }\end{array}$ & 35,9 & 2328 & 391 \\
\hline СУ-54-18 & $\begin{array}{l}\text { Углистый } \\
\text { алевролит } \\
\text { Coal siltstone } \\
\end{array}$ & $\begin{array}{l}\text { II нижний } \\
\text { II nizhny }\end{array}$ & 77,9 & 435 & 151 \\
\hline СУ-104-19 & $\begin{array}{l}\text { Уголь бурый } \\
\text { Brown coal }\end{array}$ & $\begin{array}{l}\text { II нижний } \\
\text { II nizhny }\end{array}$ & 35,1 & 1933 & 365 \\
\hline 1416 & $\begin{array}{l}\text { Уголь бурый } \\
\text { Brown coal }\end{array}$ & $\begin{array}{l}\text { II нижний } \\
\text { II nizhny }\end{array}$ & 33,8 & 1416 & 833 \\
\hline
\end{tabular}




\section{Методика исследования}

Формы нахождения германия и вольфрама исследовались с применением комплекса методов, включающих как прямые методы их определения, так и косвенные методы оценки. Выбранный комплекс методов хорошо зарекомендовал себя при изучении форм нахождения в углях и торфах редкоземельных элементов, U, Li, Ga и других элементов-примесей [12-14].

На первом этапе для предварительной оценки связи германия с органическим веществом выполнено исследование представительной выборки германиеносных углей методами математической статистики (90 проб). Для расчета использованы, помимо собственных результатов, опубликованные данные [3, 15]. Анализ выполнен методом ранговой корреляции Спирмена-Кендала, так как парная корреляция при такой большой неоднородности выборки может дать недостоверные результаты. Задача исследований оценить связь содержания германия в углях и золе угля с зольностью и выявить основные геохимические ассоциации элементов-спутников германия и вольфрама.

Для исследования роли органического и минерального вещества в концентрировании Ge и W использованы стандартные методики разделения бурого угля на групповые составляющие. Сущность метода заключается в последовательном выделении из воздушно-сухого угля битумов, гуминовых кислот и остаточного угля. Извлечение гуминовых веществ из бурых углей выполнено в соответствии с ГОСТ $9517-$ 94 [16], а битумов - по ГОСТ 10969-91 [17]. Битумы $\left(\mathrm{B}^{\text {daf }}\right)$ экстрагировались кипящим бензолом в аппарате Грефе в течение 4 часов. Бензол отгонялся, а остаток высушивали при температуре $70{ }^{\circ} \mathrm{C}$ до постоянной массы. Определение выхода общих гуминовых кислот (ГК ${ }_{\text {ob }}^{\text {daf }}$ ) выполнялось путем обработки воздушносухого остатка после извлечения битумов щелочным раствором пирофосфата натрия на встряхивателе в течение одного часа, последующей экстракцией пробы $1 \%$ раствором $\mathrm{NaOH}$ на кипящей водяной бане в течение 2 часов, осаждением гуминовых кислот избытком $5 \% \mathrm{HCl}$ и определением массы гуминовых кислот. Выход свободных гуминовых кислот (ГК $\left.{ }_{\mathrm{cB}}^{\text {daf }}\right)$ определялся таким же способом, только исключалась стадия обработки пирофосфатом натрия, которая необходима для разрушения связанных в виде солей гуминовых кислот. Остатки после извлечения гуминовых кислот $\left(\mathrm{OV}^{\mathrm{daf}}\right)$ промывали дистиллированной водой до нейтральной реакции, высушивали до воздушно-сухого состояния и рассчитывали выход на сухое беззольное топливо. Разницу от 100 \% за вычетом битумов, гуминовых кислот и остаточного угля интерпретировали как сумму низкомолекулярных органических кислот и потери.

Во всех групповых составляющих бурого угля исследованы содержания комплекса химических элементов и выполнены балансовые расчеты. Выделенные фракции изучались методом масс-спектрометрии с индуктивно связанной плазмой на спектрометре Agilent 7700x (Agilent Techn., США) в лаборатории аналитической химии Центра коллективного пользования ДВГИ ДВО РАН (г. Владивосток). Пробоподготовка велась методом химического разложения с целью избежать потерь элементов в процессе озоления. Содержание вольфрама во фракциях контролировалось также методом ИНАА. Анализ выполнен в ядерно-геохимической лаборатории МИНОЦ «Урановая геология» ТПУ (г. Томск).

Всего изучен групповой состав 2 проб бурого угля с аномально высоким содержанием германия (более $0,16 \%$ в угле) и вольфрама (более 400 г/т в угле и $0,5 \%$ в золе угля) (табл. 1)

Минеральные формы нахождения германия и вольфрама в пробах угля и золы угля изучались в МИНОЦ «Урановая геология» отделения геологии ТПУ на сканирующем электронном микроскопе «Hitachi S-3400N» с приставкой для количественного элементного анализа «Bruker». Эта методика позволяет идентифицировать и фотографировать минеральные формы микронной и нанометровой размерности, определять их элементный состав. Исследованы не только минеральные фазы, но и содержание элементов-примесей в органическом веществе. Исследовано 9 образцов с разным содержанием германия и вольфрама. Выполнено также исследование фракций группового состава. Для косвенной оценки возможных форм нахождения $\mathrm{Ge}$ и $\mathrm{W}$ во фракциях группового состава исследованы также золы фракций. Озоление проведено при температуре $800 \pm 15^{\circ} \mathrm{C}$.

Выбранный комплекс аналитических методов позволяет с высокой надежностью оценить формы нахождения и условия концентрирования вольфрама и германия в углях.

\section{Результаты исследования}

Аномально высокое содержание в углях месторождения Спецугли германия, вольфрама и других сопутствующих элементов предполагает наличие фазконцентраторов этих элементов. Это может быть как минеральное, так и органическое вещество. Если для германия давно определена ведущая роль органического вещества в его концентрировании в углях, для вольфрама такая информация не представительна и весьма противоречива.

Большие потери германия при отработке месторождения по традиционной технологической схеме, включающей стадию получения обогащенной металлом золы уноса [3], могут указывать на значительную роль неорганической формы его нахождения в угле.

\section{Результаты корреляционного анализа}

Корреляционный анализ, выполненный методом ранговой корреляции Спирмена и Кендала для 90 проб угля месторождения Спецугли, показал отсутствие значимой корреляционной связи содержания германия в угле с зольностью (кк $=-0,10)$ и значимую отрицательную связь содержания вольфрама с зольностью (кк=-0,53). В золе угля $\mathrm{Ge}$ характеризуется хотя и невысокой, но значимой отрицательной связью с зольностью (кк $=0,33)$, а вольфрам - сильной значимой отрицательной связью (кк=-0,84). Парная кор- 
реляция также показала слабую отрицательную связь германия с зольностью в угле и значимую отрицательную связь в золе угля. Для вольфрама имеет место отрицательная значимая связь его содержания с зольностью как в угле, так и в золе угля.

Это свидетельствует о накоплении повышенных концентраций Ge и W в углях из водных растворов, а не в форме кластогенных минеральных образований, и о незначительном вкладе кластогенного материала в общий баланс элементов в германиеносных углях. Причем если для вольфрама видна отчетливая связь с органическим веществом, то для германия она более сложная. Очевидно, что для германия простая зависимость: содержание германия - зольность, осложне- на еще какими-то факторами. Это может быть либо сорбционный оптимум, определяющий наиболее благоприятные условия для сорбционного его накопления при определенной зольности [5], либо наличие форм нахождения германия, не связанных с органическим веществом. Возможно также влияние обоих факторов. Характер распределения германия в угле в зависимости от зольности (рис. 3, a) показывает сорбционную природу его накопления в угле и важную роль «сорбционного оптимума» в его концентрировании. Несмотря на специфику корреляционных связей, график зависимости содержания германия в золе от зольности (рис. 3 , б) указывает на важную роль органического вещества в его накоплении.
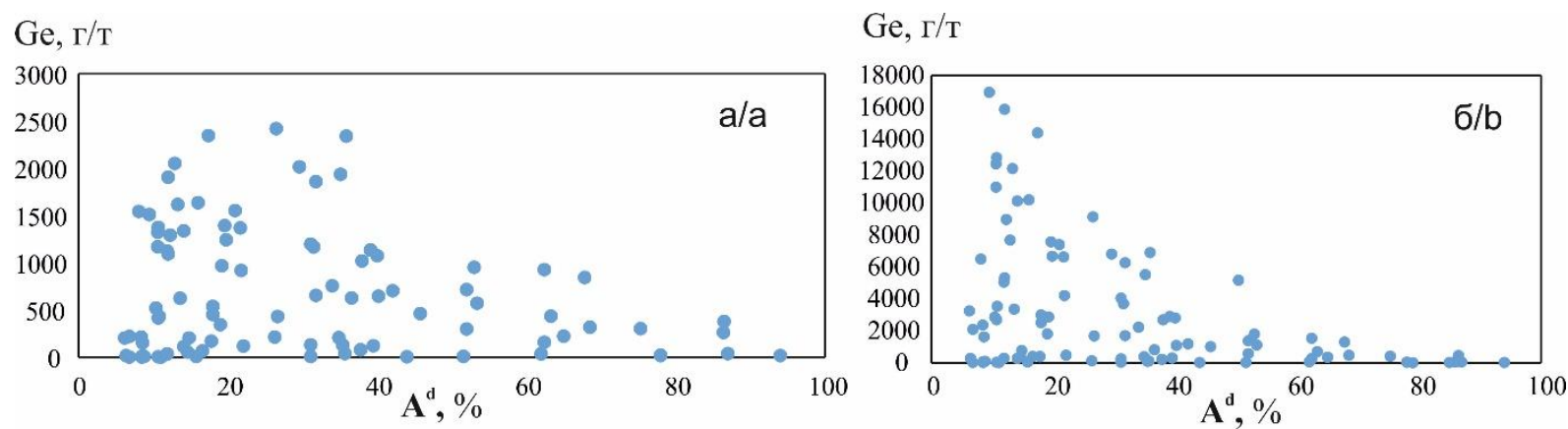

Рис. 3. Зависимость содержания германия в угле и углистом алевролите (а) и в их золе (б) от зольности

Fig. 3. Dependence of Ge content in the coal and coal siltstones (a) and their ash (b) on the ash yield

Следовательно, корреляционный анализ свидетельствует о превалирующей роли органического вещества в концентрировании вольфрама и о наличии нескольких форм концентрирования германия в углях Вместе с тем корреляционный анализ не позволяют выполнить расчет баланса соотношения органической и минеральной форм нахождения элементов в углях в настоящее время. Эти данные позволяют лишь предположить основной путь поступления элементов в торфяную залежь (угольный пласт) и оценить возможные механизмы их накопления в углях.

\section{Исследование группового состава угля}

Оценку роли органического и минерального вещества в концентрировании металлов в угле обычно осуществляют на основании данных анализа фракций угля различной плотности и с помощью уравнений связи (уравнений регрессии) содержания металла в угле и золе угля с зольностью [4]. Этот метод не позволяет учесть долю аутигенных микро- и наноминеральных фаз элементов, сформировавшихся в процессе углефикации. Более надежным методом установления такой взаимосвязи является исследование группового состава угля с последующими балансовыми расчетами.

В табл. 2, 3 приведены результаты распределения германия и вольфрама по фракциям группового состава угля. Изучены пробы с аномально высокими содержаниями этих элементов. В первом случае речь идет о пробе с содержанием $0,16 \% \mathrm{Ge}$ и $0,056 \% \mathrm{~W}$, во втором $-0,25 \% \mathrm{Ge}$ и $0,042 \% \mathrm{~W}$.
Таблица 2. Выход германия во фракции группового состава бурого угля

Table 2. Ge yield in the phases of brown coal

\begin{tabular}{|c|c|c|c|}
\hline $\begin{array}{c}\text { Групповой состав угля } \\
\text { Coal phases }\end{array}$ & \begin{tabular}{|c|} 
Выход \\
фракций, \% \\
Phase \\
yield, \% \\
\end{tabular} & $\begin{array}{c}\text { Содержа- } \\
\text { ние Ge, г/т } \\
\text { Ge content, } \\
\text { ppm }\end{array}$ & $\begin{array}{c}\text { Выход Ge во } \\
\text { фракции, \% } \\
\text { Ge yield into } \\
\text { phases, \% }\end{array}$ \\
\hline \multicolumn{4}{|c|}{ СУ $-56-18$} \\
\hline $\begin{array}{l}\text { Исходный уголь } \\
\text { Initial coal }\end{array}$ & 100 & 1600 & 100 \\
\hline $\begin{array}{l}\text { Спирто-толуольный } \\
\text { экстракт (битум) } \\
\text { Alcohol-toluene extract } \\
\text { (bitumen) }\end{array}$ & 1,3 & $<2,0$ & $<0,1$ \\
\hline $\begin{array}{l}\text { Свободные гуминовые } \\
\text { кислоты } \\
\text { Free humic acids }\end{array}$ & 10,7 & $4150^{*}$ & 27,0 \\
\hline $\begin{array}{l}\text { Регенерированные } \\
\text { гуминовые кислоты } \\
\text { Recovered humic acids }\end{array}$ & 2,5 & $12430 *$ & 20,0 \\
\hline $\begin{array}{l}\text { Остаточный уголь } \\
\text { Residual coal }\end{array}$ & 85,5 & 1000 & 53,0 \\
\hline \multicolumn{4}{|c|}{ СУ-103-19 } \\
\hline $\begin{array}{l}\text { Исходный уголь } \\
\text { Initial coal }\end{array}$ & 100 & 2540 & 100 \\
\hline $\begin{array}{l}\text { Спирто-толуольный } \\
\text { экстракт (битум) } \\
\text { Alcohol-toluene extract } \\
\text { (bitumen) }\end{array}$ & 1,1 & $<2,0$ & $<0,1$ \\
\hline $\begin{array}{l}\text { Свободные гуминовые } \\
\text { кислоты } \\
\text { Free humic acids }\end{array}$ & 24,4 & $6110^{*}$ & 59,3 \\
\hline $\begin{array}{l}\text { Регенерированные } \\
\text { гуминовые кислоты } \\
\text { Recovered humic acids }\end{array}$ & 5,6 & $7940 *$ & 17,7 \\
\hline $\begin{array}{l}\text { Остаточный уголь } \\
\text { Residual coal }\end{array}$ & 68,9 & 840 & 23,0 \\
\hline
\end{tabular}

Примечание: *- получено расчетным путем.

Note: * - obtained by calculation. 
Таблица 3. Выход вольфрама во фракиии группового состава бурого угля

Table 3. W yield in the phases of brown coal

\begin{tabular}{|c|c|c|c|}
\hline $\begin{array}{c}\text { Групповой состав угля } \\
\text { Coal phases }\end{array}$ & $\begin{array}{l}\text { Выход } \\
\text { фрак- } \\
\text { ций, \% } \\
\text { Phase } \\
\text { yield, \% }\end{array}$ & $\begin{array}{l}\text { Содер- } \\
\text { жание } \\
\mathrm{W}, \mathrm{\Gamma} / \mathrm{T} \\
\mathrm{W} \text { con- } \\
\text { tent, ppm }\end{array}$ & $\begin{array}{c}\text { Выход W } \\
\text { во фрак- } \\
\text { ции, \% } \\
\text { W yield into } \\
\text { phases, \% }\end{array}$ \\
\hline \multicolumn{4}{|c|}{ СУ-56-18 } \\
\hline $\begin{array}{l}\text { Исходный уголь } \\
\text { Initial coal }\end{array}$ & 100 & 563 & 100 \\
\hline $\begin{array}{l}\text { Спирто-толуольный } \\
\text { экстракт (битум) } \\
\text { Alcohol-toluene extract } \\
\text { (bitumen) }\end{array}$ & 1,3 & $<2,0$ & $<0,1$ \\
\hline $\begin{array}{l}\text { Свободные гуминовые } \\
\text { кислоты } \\
\text { Free humic acids }\end{array}$ & 10,7 & $5226^{*}$ & 99,3 \\
\hline $\begin{array}{l}\text { Регенерированные } \\
\text { гуминовые кислоты } \\
\text { Recovered humic acids } \\
\end{array}$ & 2,5 & $58^{*}$ & 0,3 \\
\hline $\begin{array}{l}\text { Остаточный уголь } \\
\text { Residual coal }\end{array}$ & 85,5 & 3,1 & 0,5 \\
\hline \multicolumn{4}{|c|}{ СУ-103-19 } \\
\hline $\begin{array}{l}\text { Исходный уголь } \\
\text { Initial coal }\end{array}$ & 100 & 417 & 100 \\
\hline $\begin{array}{l}\text { Спирто-толуольный } \\
\text { экстракт (битум) } \\
\text { Alcohol-toluene extract } \\
\text { (bitumen) } \\
\end{array}$ & 1,1 & $<2,0$ & $<0,1$ \\
\hline $\begin{array}{l}\text { Свободные гуминовые } \\
\text { кислоты } \\
\text { Free humic acids }\end{array}$ & 24,4 & $1655^{*}$ & 97,9 \\
\hline $\begin{array}{l}\text { Регенерированные } \\
\text { гуминовые кислоты } \\
\text { Recovered humic acids }\end{array}$ & 5,6 & $36,7^{*}$ & 0,5 \\
\hline $\begin{array}{l}\text { Остаточный уголь } \\
\text { Residual coal }\end{array}$ & 68,9 & 9,6 & 1,6 \\
\hline
\end{tabular}

Примечание: * - получено расчетным путем. Note: *-obtained by calculation.

Как следует из этих данных, значительная доля германия - от 47 до 77 \%, и более 98 \% вольфрама переходит в щелочную вытяжку. При этом вольфрам практически весь извлекается $1 \% \mathrm{NaOH}$ во фракцию, получившую название свободных гуминовых кислот. Использование пирофосфата натрия лишь незначительно увеличивает выход вольфрама в щелочную вытяжку, что свидетельствует о его преимущественном концентрировании в мобильных органических веществах. В эту вытяжку входят собственно гуминовые кислоты, фульвокислоты и другие низкомолякулярные кислоты. Вероятно, сюда же могут переходить и ионные формы элемента, не связанные с органическим веществом. Оценить роль каждой из них достаточно сложно, но приближенные оценки показывают, что основная часть вольфрама, извлекаемая в щелочную вытяжку, не осаждается с гуминовыми кислотами в процессе ее подкисления $5 \% \mathrm{HCl}$, а остается в растворе. Приблизительное соотношение можно оценить по данным табл. 4.

При этом следует понимать, что прямое определение вольфрама в гуминовых кислотах несколько занижено по сравнению с его содержанием в этих веществах в исходном угле, так как в процессе экстракции их из исходного угля они насыщаются избытком натрия, который не извлекается полностью при по- следующем промывании извлеченных твердых гуминовых кислот дистиллированной водой. Кроме того, возможно частичное разрушение первичных микроминеральных фаз вольфрама нагретым раствором $1 \%$ $\mathrm{NaOH}$ и переходом их в щелочной раствор. Тем не менее нет сомнений, что превалирующая часть вольфрама в исследуемых образцах связана с мобильным органическим веществом. Этот вывод подтверждается и данными специализированных электронномикроскопических исследований. Несмотря на масштабные исследования обогащенных вольфрамом проб, было выявлено всего одно зерно нанометровой размерности, по составу соответствующее шеелиту.

Таблица 4. Распределение германия и вольфрама по фракииям в щелочной вытяжке из бурого угля (проба СУ-103-19)

Table 4. Ge and $W$ distribution in the phases in alkaline extract of the brown coal (sample $S U$-103-19)

\begin{tabular}{|l|c|c|}
\hline \multirow{2}{*}{$\begin{array}{c}\text { Показатели } \\
\text { Indexes }\end{array}$} & \multicolumn{2}{|c|}{ Щелочная вытяжка/Alkaline extract } \\
\cline { 2 - 3 } & $\begin{array}{c}\text { Гуминовые } \\
\text { кислоты } \\
\text { Нumic } \\
\text { acids }\end{array}$ & $\begin{array}{c}\text { Низкомолекулярные } \\
\text { кислоты, ионы, нано- } \\
\text { минералы } \\
\text { Low-molecular acids, } \\
\text { ions, nanominerals }\end{array}$ \\
\hline $\begin{array}{l}\text { Выход фракций, \% } \\
\text { Phase уield, \% }\end{array}$ & 24,8 & 5,2 \\
\hline $\begin{array}{l}\text { Содержание Ge, г/т } \\
\text { Ge content, g/t }\end{array}$ & 583 & $34430 *$ \\
\hline $\begin{array}{l}\text { Выход Ge во фракции, \% } \\
\text { Ge уield into the phases, \% }\end{array}$ & 5,7 & 71,2 \\
\hline $\begin{array}{l}\text { Содержание W, г/т } \\
\text { W content, g/t }\end{array}$ & 542 & $5223 *$ \\
\hline $\begin{array}{l}\text { Выход W во фракции, \% } \\
\text { W уield into the phases , \% }\end{array}$ & 46,2 & 51,7 \\
\hline
\end{tabular}

Примечание: * - получено расчетным путем. Note: $*$ calculated data.

В случае с германием картина существенно более сложная. В щелочную вытяжку переходит от 47 до 77 \% германия. При этом при использовании для экстракции гуминовых кислот только $1 \% \mathrm{NaOH}$ (свободные гуминовые кислоты) в остаточном угле остается 40,7 \% германия в пробе СУ-103-19 и 73,6 \% в пробе СУ-56-18. Извлечение гуминовых кислот с использованием пирофосфата натрия для регенерирования кислот из гуматов уменьшает долю германия в остатке до 23 и 52,8 \%, соответственно (табл. 2). Здесь также имеется ряд неопределенностей. Из этих данных не ясно, какая часть связанного с органикой германия не была извлечена в щелочную вытяжку и, соответственно, какова доля минеральной формы германия в данном образце остаточного угля. Частично ответ на этот вопрос дают результаты СЭМ, но они не позволяют надежно оценить соотношение органических и минеральных фаз германия в остаточном угле, а дают лишь приблизительные оценки. Очевидно лишь, что в остаточном угле органическое вещество также обогащено германием.

\section{Электронно-микроскопические исследования}

В последнее время, благодаря внедрению современной сканирующей электронной микроскопии, появилась возможность прямого количественного 
определения элементов в различных минеральных и органических компонентах в углях. Исследование органического вещества 9 проб угля месторождения Спецугли показало, что содержание германия в нем варьирует весьма существенно и может достигать 2 \%. Эти факты подтверждают ведущую роль органического вещества в концентрировании германия в угле. Такие же данные получены ранее для углей месторождения Спецугли методом ICP MS с лазерной абляцией $[7,11]$. В этих работах было доказано, что из мацералов германием наиболее обогащен $\Delta$ витринит, в меньшей степени - аттрито-витринит. В целом в органическом веществе германий распределен довольно неоднородно (рис. 4). В значительной части органического вещества угля его содержание не превышает предела определения анализа. Согласно данным ICP MS с лазерной абляцией, содержание $\mathrm{Ge}$ в $\Delta$-витрините превосходит его содержание в аттрито-витрините в 2-4 раза [3]. Эти данные не согласуются с результатами исследования органического вещества крупных германий-угольных месторождений Линканг и Вулантуга, согласно которым германий в органическом веществе распределен однородно [18].
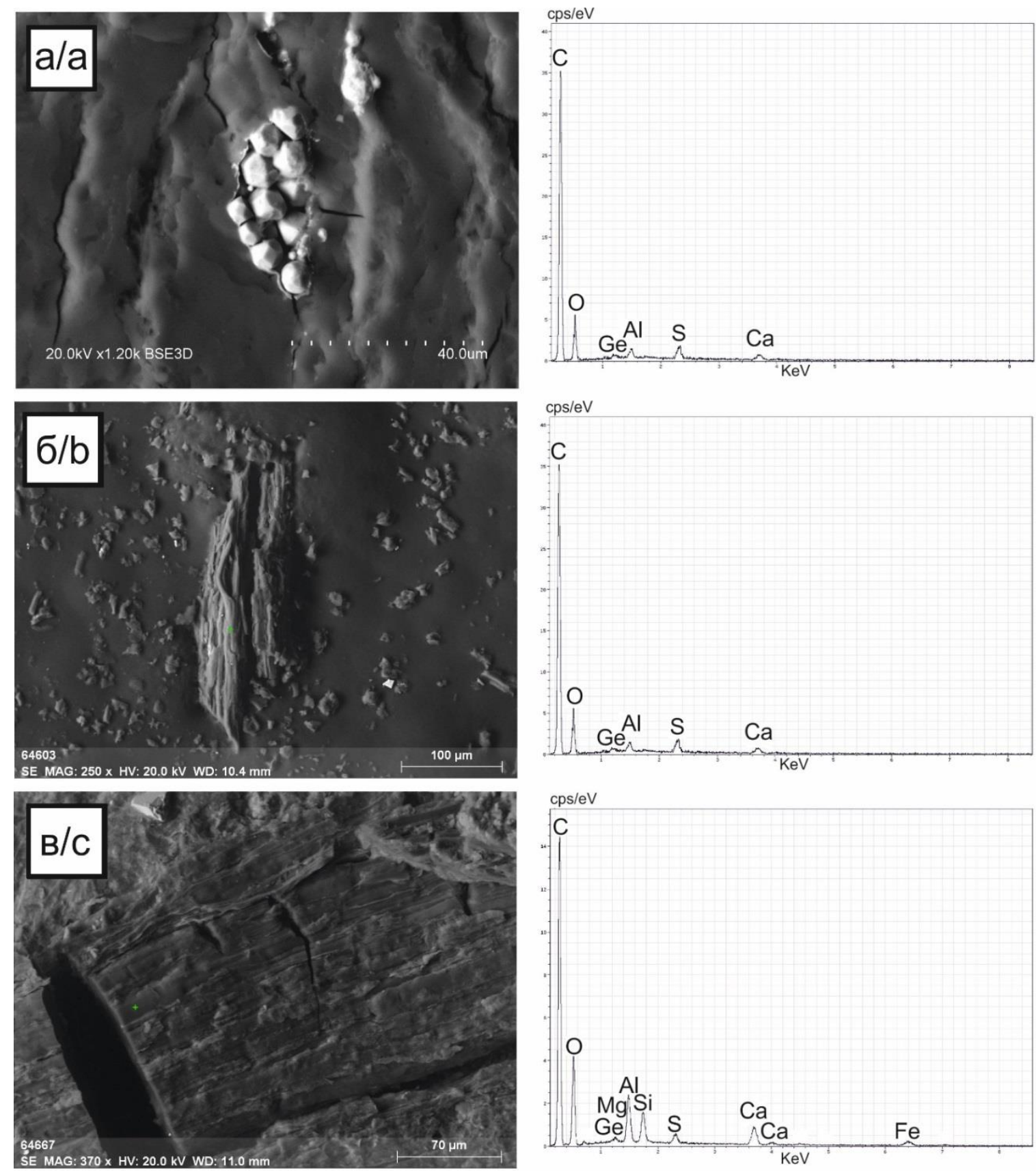

Pис. 4. Электронно-микроскопические снимки и рентгеновские спектры германийсодержащего органического вещества угля. Содержание германия: а) 0,84\%; б) 0,45\%; в) 0,15\%

Fig. 4. Electron-microscopic pictures and roentgen spectra of the Ge-bearing coal organic matter. Ge content is: a) 0,84\%; b) $0,45 \%$; c) $0,15 \%$ 
Ведущая роль органического вещества в накоплении германия в углях месторождения Спецугли подтверждается также данными прямого определения его содержания в извлеченных гуминовых кислотах и в золе гуминовых кислот. Согласно этим оценкам, содержание германия в ГК также достаточно неоднородно и достигает десятых долей процента. В золе гуминовых кислот максимальное содержание превышает 1 \%. При этом золы ГК часто наряду с германием обогащены сурьмой и вольфрамом. Содержание сурьмы и вольфрама в исследуемых золах ГК обычно существенно выше, чем содержание германия. Следует отметить, что извлеченные в щелочную вытяжку гуминовые кислоты при прямом определении в них германия масс-спектрометрическим методом с индуктивно связанной плазмой отличаются сравнительно невысоким его содержанием, не превышающим 0,1 \%. По данным СЭМ оно несколько выше, но также не превышает 0,2%. Либо при получении щелочной вытяжки часть германия переходит из гуминовых кислот в раствор, либо германий изначально в большей степени приурочен к низкомолекулярным кислотам и, возможно, частично сконцентрирован в легкорастворимых наноминеральных фазах.

Анализ органического вещества фракций остаточного угля, полученных после извлечения битумов и ГК, показывает, что здесь также имеются фазы высокообогащенной органики, содержащей до 0,1 \% гер- мания (рис. 5). По-видимому, в углях помимо комплексных гуматов, извлеченных в щелочную вытяжку, имеются и другие формы соединений германия с органическим веществом. При этом наряду с германием в органическом веществе остаточного угля отмечено аномально высокое содержание молибдена (до $0,13 \%)$, но не установлены вольфрам и сурьма.

Исследование пирита, считавшегося одним из возможных минералов- концентраторов германия, показало, что содержание германия в нем ниже пределов обнаружения анализа. Пириты в углях представлены кристаллами различного габитуса: гексаэдры, октаэдры, ромбододекаэдры и другие сложные формы с преобладанием гексаэдров. В то же время на поверхности пирита обнаружены прозрачные алюмосиликатные (силикатные) пленки (рис. 6). Каждый кристалл пирита обернут в такую пленку, как в кокон. При механическом воздействии пленка разрушается. Пленка существенно обогащена германием. Мелкие размеры кристаллов пирита и покрывающих их пленок не позволяют получить «чистые» энерго-дисперсионные спектры без влияния фона, но даже в этом случае в них содержание германия определяется на уровне 0,15-0,4 \%. Обогащение пленок хорошо видно при картировании распределения германия на участке с пиритами, покрытыми такими пленками (рис. 6). Такие пленкоподобные кремнистые агрегаты, обогащенные германием, встречены и вне связи с пиритом.
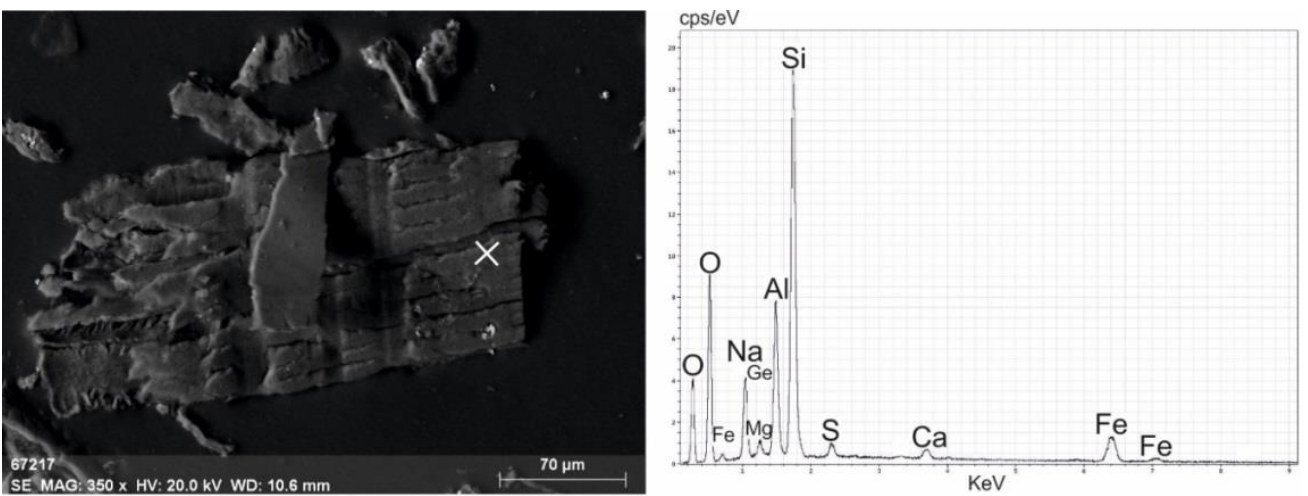

Pис. 5. Электронно-микроскопический снимок органического вещества угля, оставшегося после извлечения битумов и гуминовых веществ и его рентгеновский спектр

Fig. 5. Electron-microscopic picture of the organic matter of the coal residue after the bitumen and humic substances extraction and its roentgen spectrum
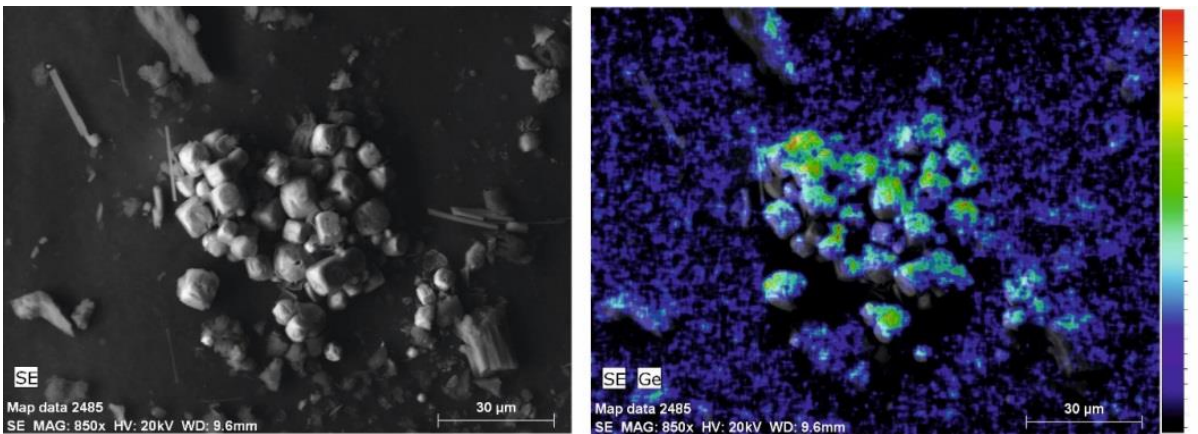

Рис. 6. Электронно-микроскопический снимок скоплений пирита, покрытого алюмосиликатной пленкой (слева) и карта распределения германия (справа)

Fig. 6. Electron-microscopic picture of the pyrite cluster covered with aluminosilicate film (left) and a map of Ge distribution (right) 
В пиритах, не имеющих такого алюмосиликатного (силикатного) покрытия, значимых содержаний германия не выявлено (рис. 7). В них может присутствовать примесь мышьяка. Эти результаты корреспонди- руют с данными, полученными для германиевых месторождений Линканг и Вулантуга, согласно которым пирит имеет важное значение в концентрировании As, $\mathrm{Hg}$ и Tl, но не связан с накоплением Ge и W $[19,20]$.
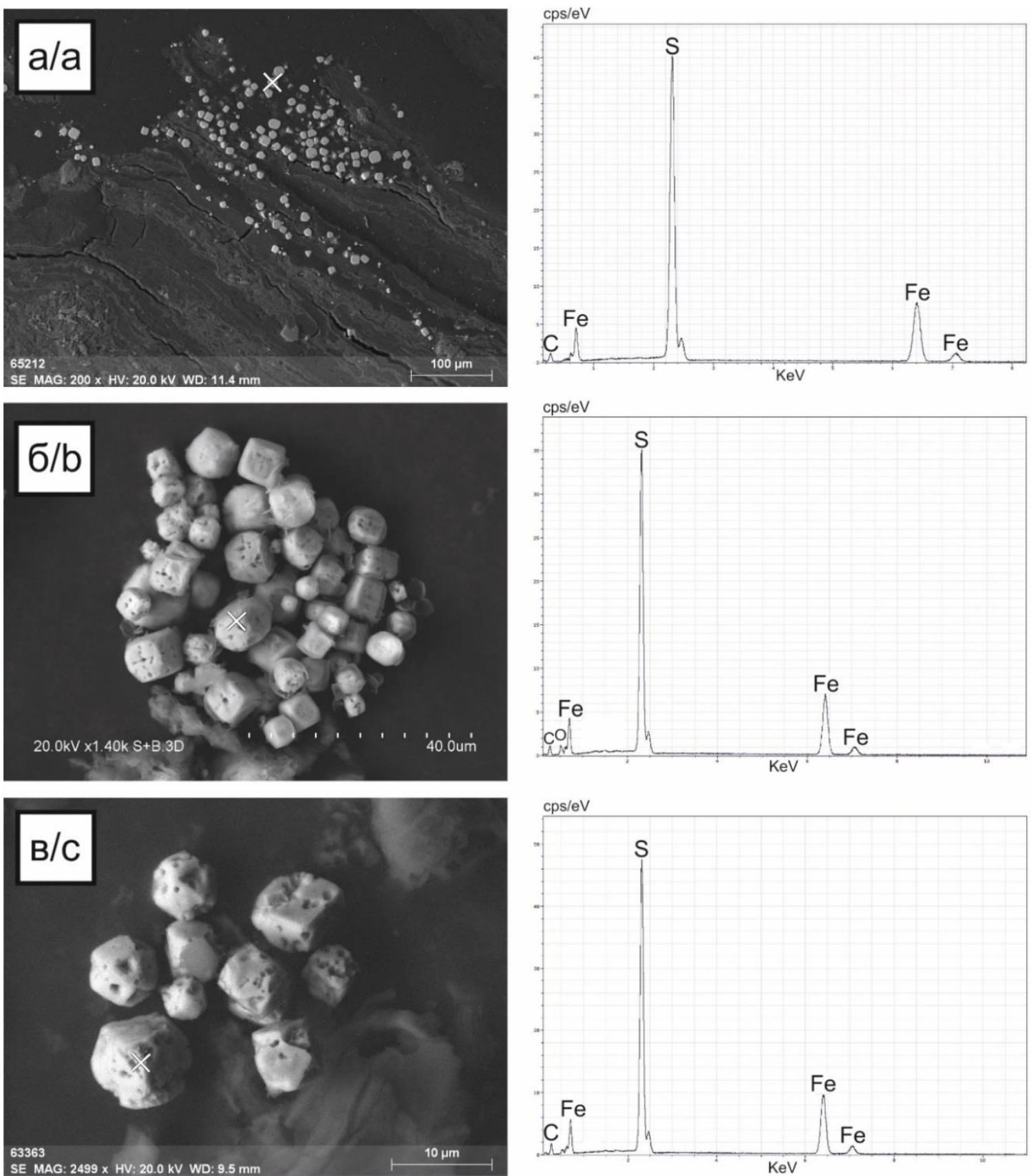

Рис. 7. Электронно-микроскопический снимок пиритов (а) и их рентгеновский спектр. Полированный шллф. Снимки пиритов со следами коррозии $(б$, в) и их рентгеновские спектры. Сколы образиов

Fig. 7. Electron-microscopic picture of pyrites (a) and their roentgen spectra. Polished thin section. The pictures of pyrite with instances of corrosion $(b, c)$ and their roentgen spectra. Fractures of the samples

В связи с тем, что скопления пирита часто приурочены к микротрещинам в органическом веществе, образуют скопления и линзочки, очевидно, что сформировались они после торфяной стадии, возможно, в результате сульфат-редукции сульфатов, характерных для углей месторождения в целом. Важной особенностью этих пиритов является наличие на поверхности следов коррозии в виде канавок, выемок, отверстий разной формы (рис. 7). После этого отдельные блоки кристаллов пирита были упакованы в прозрачные пленкоподобные «коконы». Соответственно, покрывающие пирит пленки еще более поздние и связаны с отложением свободного кремнезема, формирующегося, вероятно, в результате его выноса при преобразовании полевых шпатов в каолинит при образовании коры выветривания. Наличие такого избыточного аутигенного кремнезема в аргилли- 
тах месторождения отмечено Я.Э. Юдовичем при проведении литохимического анализа пород и золы углей месторождения Спецугли [5]. Возможно, эти пленки представлены силикогерманатом. Следует заметить, что такие пленки отмечены и вне связи с конкретными зернами пирита. Эти факты свидетельствуют о том, что формирование германиевой минерализации в месторождении может быть более растянуто во времени, чем предполагалось ранее, и не ограничивается торфяной стадией. Возможно даже, что накопление германия происходит и в настоящее время. Об этом свидетельствует состав дренирующих через пласт III нижний современных кислых сульфатных вод, аномально обогащенных германием (57 мкг/л).

В углях, расположенных вблизи выступа фундамента в центре месторождения, установлены много- численные мелкие тонкодисперсные агрегаты, представленные преимущественно гидроокислами железа с примесью минеральных фаз алюмосиликатного и сульфатного состава. Содержание германия в этих минеральных агрегатах колеблется от 2,6 до 6,2% (рис. 8). Помимо германия в них содержится от долей процента до 4,8 \% сурьмы, иногда отмечается мышьяк до $2 \%$.

Высокожелезистые минеральные фазы, соответствующие по составу ярозиту, были выявлены в высокогерманиеносных углях пласта III нижний (рис. 8, c).

Аналогичные по составу минеральные фазы встречаются и в углефицированной древесине, извлеченной из межпластовых песчаных отложений. Во внешней оболочке распространены многочисленные оксиды железа (рис. 9, а), содержащие до 5 \% германия.
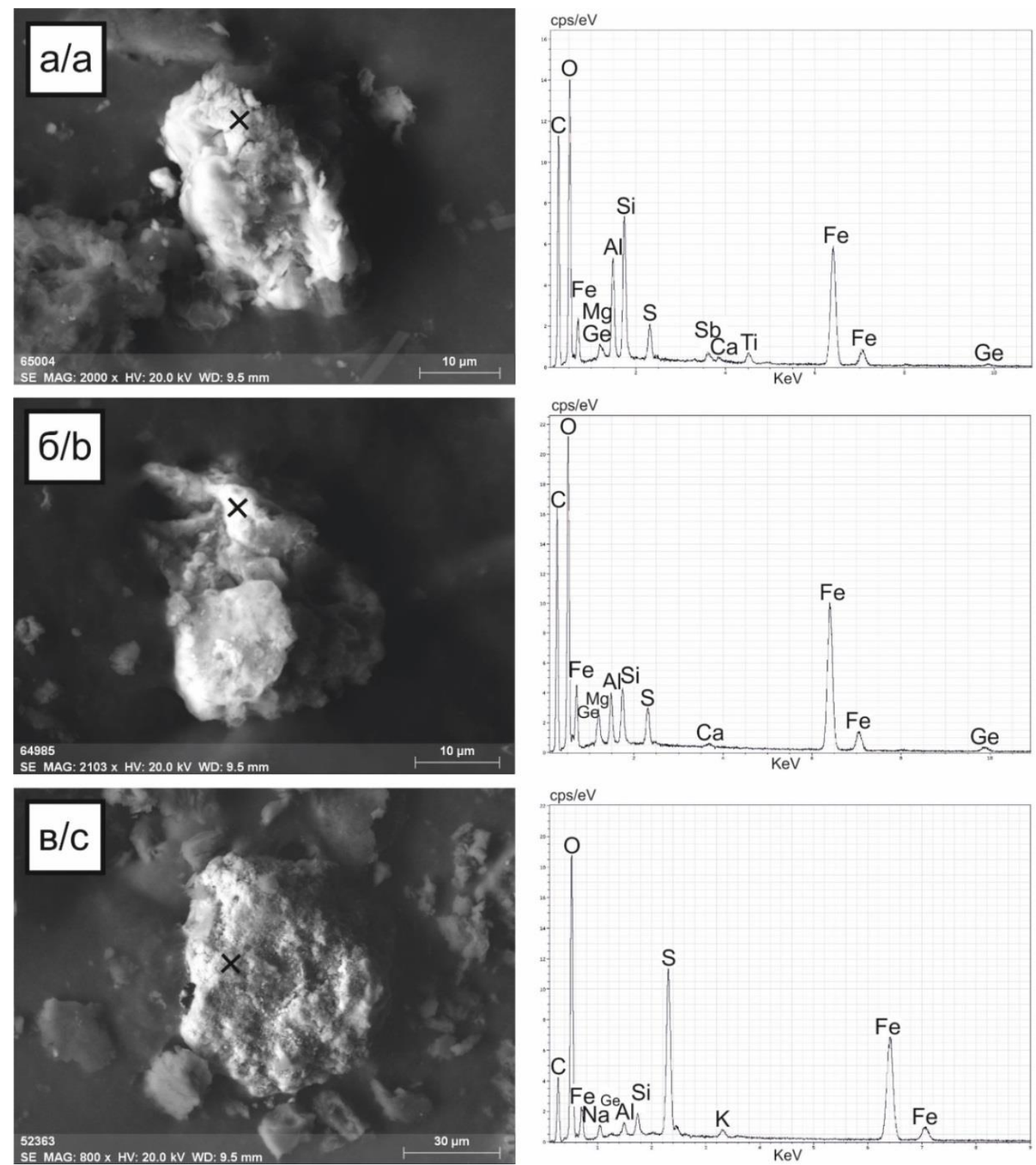

Pис. 8. Электронно-микроскопическиие снимки высокожелезистых микроагрегатов с германием и их рентгеновские спектры: а) гидрогётит, 2,7\% Ge; б) гидрогётит, 6,2\% Ge; в) ярозит, 0,1\% Ge

Fig. 8. Electron-microscopic pictures of high-iron microcongeries with Ge and their roentgen spectra: a) hydrogoethite, 2,7\% $\mathrm{Ge}$; b) hydrogoethite, 6,2\% Ge; c) jarosite, 0,1\% Ge 

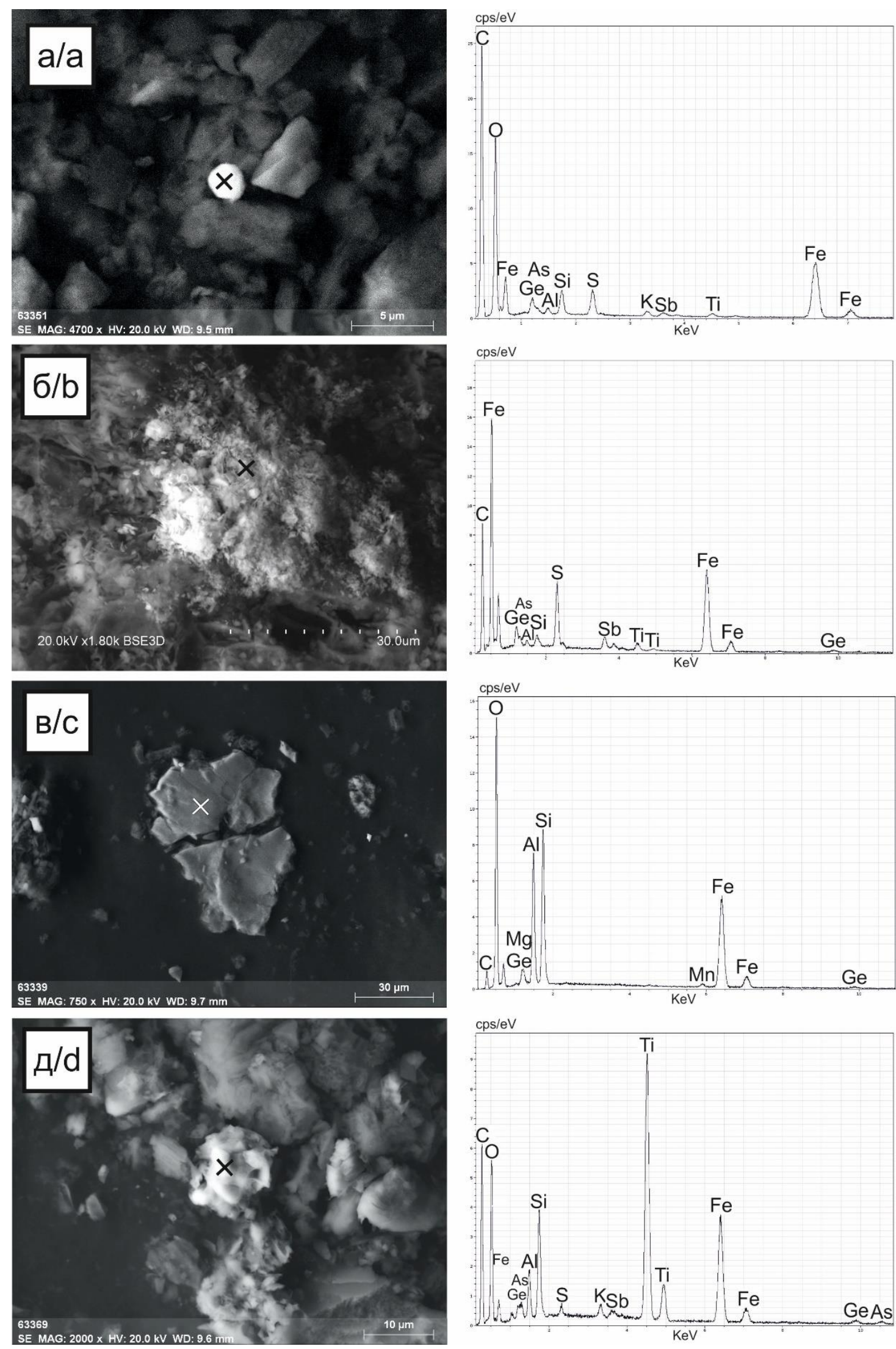

Pис. 9. Электронно-микроскопическиие снимки германиеносных оксидов железа (a) 4 \% Ge; сульфатов железа (б) 6,0 \%, железо-магнезиального хлорита (в) 1,8\% Gе и псевдорутила (д) 2 \% в ископаемой древесине и их рентгеновские спектры

Fig. 9. Electron-microscopic pictures of Ge-bearing iron oxides (a) 4,5\% Ge; iron sulfates (b) $6 \%$, iron-magnesial chlorite (c) $1,8 \% \mathrm{Ge}$, and pseudorutil (d) in the fossil wood and their roentgen spectra 
Землистые агрегаты сульфата железа (рис. 9, б) помимо германия (от 3,5 до $6 \%$ ) содержат примеси $\mathrm{Sb}, \mathrm{Ti}$ и As. Содержание сурьмы изменяется от 4,5 до 9,5\%.

В углефицированной древесине установлены и другие содержащие германий минеральные фазы, такие как железо-магнезиальный хлорит (рис. 9, в) и псевдорутил (рис. 9, д), содержащий до 2 \% германия.

Оксиды железа, обогащенные германием, встречаются в углефицированной древесине, как во внешней части обломка, так и внутри. Сульфаты железа были обнаружены только в самой древесине внутри образца. В органическом веществе внешней части образца содержание германия (от 0,1 до $2 \%$ ) выше, чем во внутренней зоне (от «ниже предела обнаружения» до $0,85 \%$ ). Выявленный факт такой зональности распределения германия в углефицированных обломках хорошо согласуется с гидрогенной моделью накопления в них германия [21].

Все минеральные фазы с высоким содержанием германия и с переменным количеством сурьмы и мышьяка представлены агрегатами, обогащенными окисным железом в форме гётита или гидрогётита. Возможность соосаждения германия с гидроокислами железа доказана экспериментально еще в средине прошлого столетия [22]. При этом здесь же встречаются сульфаты кальция (ангидрит), бария (барит). В этих комплексных полиминеральных агрегатах также присутствует в количестве 1-2 \% сульфатная фаза. Из безжелезистых минеральных фаз с германием выявлены только алюмосиликатные (силикатные) пленки не выясненной минеральной принадлежности.

В углях, непосредственно примыкающих к выступу фундамента и залегающих на коре выветривания грейзенизированного гранита, выявлены железомарганцевые стяжения, обогащенные германием, мышьяком и вольфрамом (рис. 10). Хорошо видна их вторичная природа по отношению к поверхности, на которой они сформировались.
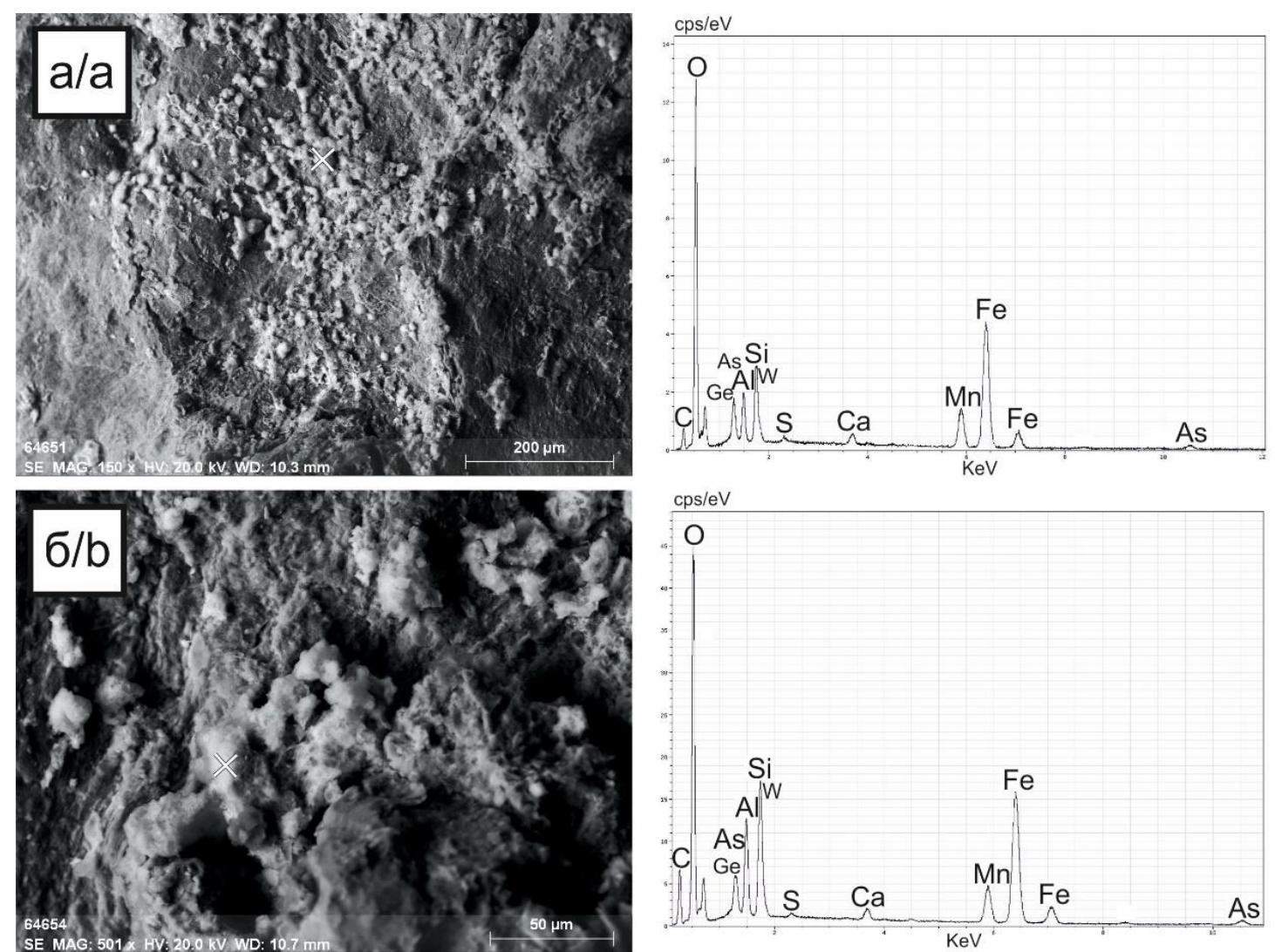

Рис. 10. Электронно-микроскопические снилки железо-марганцевых корок в угле и их рентгеновские спектры: a) $\mathrm{Ge}-0,24 \%, \mathrm{As}-5,1 \%, \mathrm{~W}-1,4 \%$; б) $\mathrm{Ge}-0,47 \%$, As-5,5\%, W-2,0\%

Fig. 10. Electron-microscopic pictures of the iron-manganese crusts in the coal and their roentgen spectra: a) Ge-0,24\%, As $-5,1 \%, W-1,4 \%$; b) $G e-0,47 \%, A s-5,5 \%, W-2,0 \%$

Никаких других минеральных фаз вольфрама за исключением одного обломка шеелита микронного размера в углях месторождения выявлено не было. По-видимому, только в непосредственной близости от источника вольфрам соосаждался с железом и марганцем. В других случаях он мигрировал и концентрировался в органическом веществе в форме комплексных гуматов.
Следует отметить, что подобные $\mathrm{Fe}-\mathrm{Mn}$ «корки» вблизи фундамента, но не связанные с углем, отличаются низким содержанием как германия $(1,0$ г/т), мышьяка $(2,1$ г/т), так и вольфрама (7,1 г/т). По-видимому, здесь сыграла роль более кислая восстановительная среда минералообразования в угольном пласте (палеоторфе), в сравнении с окислительной средой, характерной для формирующейся коры выветривания. 


\section{Обсуждение результатов}

В результате исследования форм нахождения германия и вольфрама в высоко германиеносных углях месторождения Спецугли выявлены их многообразные органические и минеральные формы.

Для вольфрама формы нахождения ограничиваются органически связанными формами (98-99 \%) и незначительными количествами минеральных фаз, доля которых в общем балансе металла в месторождении не превышает 1-2 \%. В органическом веществе вольфрам сконцентрирован в составе гуминовых кислот, гуматов и, предположительно, в сорбированных формах на органическом веществе. Минеральные фазы представлены зерном шеелита и агрегатом $\mathrm{Fe}$ Mn состава, содержащим 1,4 \% W. Эти данные не противоречат имеющейся информации о ранее установленных формах нахождения вольфрама в углях.

Формы нахождения вольфрама в углях в целом изучены недостаточно и в существенно меньшей степени, чем формы германия. Большинство из немногочисленных сведений, обобщенных в работе Я.Э. Юдовича и М.П. Кетрис [23], основаны на косвенных методах оценки доли минеральной и органической форм вольфрама. В большинстве оценок отмечается преобладание его органической формы нахождения. Согласно исследованиям фракций различного удельного веса германиеностных углей Новиковского (о. Сахалин) и Ангренского (Узбекистан) месторождений, выполненным в Институте горючих ископаемых, основная масса вольфрама в бурых углях этих месторождений связана с органическим веществом [24]. Селективное выщелачивание различными кислотами разных углей США показало инертность вольфрама $[25,26]$, что позволило предположить нахождение вольфрама или в органическом веществе, или в оксидах. Из недавно опубликованных данных следует, что в углях распространены как органические, так и минеральные формы вольфрама. Так, микрозондовое исследование лигнитизированной древесины в породах вскрыши Павловского месторождения Приморья показало присутствие самородного вольфрама, сложного хлорида и бромида вольфрама [27]. Электронно-микроскопические исследования, выполненные для Ушумунского и Сутарского месторождений угля в Забайкалье, показали, что в них преобладают минеральные формы вольфрама $[28,29]$. Для Ушумунского месторождения - это вольфрам в самородной форме, в форме интерметаллидов $\mathrm{W}-\mathrm{Co}$ и в форме оксидов. В углях Сутарского месторождения отмечены шеелит, вольфрамит, гюбнерит, ферберит и штольцит наряду со сложными по составу микроминеральными образованиями. Штольцит выявлен и в углях германиеносного месторождения Вылче Поле в Болгарии [30]. С другой стороны, данные EXAFS-спектроскопии подтверждают отсутствие или незначительный вклад отдельных богатых вольфрамом минералов, таких как шеелит или ферберит, в балансе массы W в исследованных образцах из крупнейших германиевых месторождений Вулантуга и Линканг [18].

Формы нахождения германия в месторождении Спецугли существенно более разнообразны, чем формы вольфрама. Вопреки устоявшемуся представлению о незначительной роли минеральных форм в концентрировании германия, в высокогерманиеносных углях этого месторождения их значение может быть весьма существенным. При этом в результате исследований в целом подтверждена ведущая роль органических форм нахождения германия в общем балансе металла.

Исследование форм нахождения германия имеет почти вековую историю. Он начал изучаться в углях одним из первых элементов-примесей. Установлена ведущая роль органического вещества в накоплении германия в углях. Показано, что наиболее обогащены им витреновые угли. Еще в 1950-е гг. экспериментально доказано [31], что в торфе, как прекурсоре угля, германий концентрируется в следующих пропорциях: $80 \%$ извлекается в щелочной раствор (1\% $\mathrm{NaOH})$ и около $20 \%$ остается в нерастворимом остатке. При этом 32,4 \% выделяется в качестве гуминовых кислот, а 46,5 \% содержится в сернокислом растворе фульвокислот. В углях это соотношение нарушается в связи с процессами конденсации фульвокислот. Современные данные показывают, что в германиеносных бурых углях соотношение органической и минеральной форм германия может существенно варьировать. Так, согласно результатам исследований германиеносных углей месторождения Спецугли [6], не менее $60 \%$ германия связано с мобильным органическим веществом, в том числе от 25 до 60 \% приходится на комплексные соединения германия с гуминовыми кислотами, и 8-39 \% связано с низкомолекулярной фракцией органического вещества, не осаждаемой кислотами. По данным М.Я. Шпирта [4], германий сосредоточен в органическом веществе углей в виде комплексных гуматов (75-96 \%) и германийорганических соединений (3-24 \%). Количество неорганических соединений (силикогерманатов) не превышает 2-3 \% и повышается в некоторых германийсодержащих углистых породах (2-9 \%). По другим сведениям, в минеральной форме находится от 1,7 до 10,3 [32] или от 7 до 24 \% германия [33]. В.И. Вялов и др. [7], используя методику ICP MS с лазерной абляцией, впервые наглядно показали на примере германиеносных углей месторождения Спецугли, что основным носителем германия в углях является $\Delta$ витринит. В связи с тем, что степень разложения органического вещества $\Delta$-витринита выше, чем аттрито-витринита, в $\Delta$-витрините большее количество гуминовых и фульвокислот, поэтому концентрация $\mathrm{Ge}, \mathrm{Mo}, \mathrm{W}, \mathrm{Sb}$ в $\Delta$-витрините максимальна [7]. Сходная картина получена для месторождений Вулантуга и Линканг (Китай) с использованием электронного микрозонда [34]. Показано, что Ge в месторождениях встречается исключительно в мацералах, и не было идентифицировано Ge-содержащих минералов в углях с высоким содержанием Ge. Противоречат этим данным результаты электронно-микроскопических исследований, выполненных международным коллективом исследователей [35], установивших в составе германиеносных углей месторождения Вулантуга микрочастицы ( $<0,5$ мкм) оксидов германия. Исполь- 
зовав метод EXAFS спектроскопии, В. Etschmann и др. [18] показали на примере высокогерманиеносных углей этих месторождений, что Ge в органическом веществе распределен однородно. Следует заметить, что вывод по распределению германия в этих двух месторождениях противоречит и многочисленным другим данным, так как известно, что германий концентрируется по-разному в разных группах органического вещества.

Исследование высокогерманиеносных углей месторождения Спецугли показало, что от 47 до $77 \%$ $\mathrm{Ge}$ выходит в щелочной экстракт при извлечении гуминовых кислот. При этом в твердый осадок гуминовых кислот выделяется лишь небольшая часть германия. Остальной $\mathrm{Ge}$ остается в растворе. Не ясно, в какой форме содержится германий, извлеченный в вытяжку, но не связанный с гуминовыми кислотами. Согласно опубликованным данным для месторождения Спецугли, но для существенно менее обогащенных германием углей, на комплексные соединения с гуминовыми кислотами приходится 25-60 \% от общего его количества в органическом веществе и 8-39 \% связано с низкомолекулярными кислотами [6]. Кроме того, по данным А.С. Якушевич с соавторами, в исследованных ими пробах до 24 \% германия при щелочной экстракции переходит из неорганических соединений в экстракт в форме минеральных наночастиц, стабилизированных органическим веществом [6]. В рассматриваемых нами случаях в щелочной вытяжке резко преобладает доля $\mathrm{Ge}$, связанного с веществами, не осаждаемыми с твердыми гуминовыми кислотами. Какая-то его доля в этом растворе, очевидно, связана с фульвокислотами и другими низкомолекулярными кислотами. Остальная часть $\mathrm{Ge}$ может быть связана с неорганическим веществом, представленным, в частности, кремниевой кислотой, с которой германий способен давать соединения типа силикогерманатов. На возможную роль кремнекислоты указывают факты выпадения кремнезема при выпаривании щелочного раствора, полученного при извлечении гуминовых кислот из углей месторождения [6]. Согласно этим же данным, из золы угля в раствор $1 \% \mathrm{NaOH}$ переходит до $17 \%$ германия. Известно, что $\mathrm{NaOH}$ способен переводить минеральные формы $\mathrm{Ge}$ в раствор в форме германатов и полигерманатов [36]. Вероятно, процесс извлечения гуминовых кислот сопровождается частичным высвобождением $\mathrm{Ge}$ в щелочной раствор и из его минеральных фаз. Эти результаты согласуются с экспериментальными данными для германиеносных торфов. Установлена высокая доля германия $(58,1 \%)$, не связанного с гуминовыми кислотами, в щелочной вытяжке $(1 \% \mathrm{NaOH})$ из торфа [31]. Высказано предположение о его связи с фульвокислотами.

Минеральные фазы германия в германиеносных углях месторождения Спецугли достаточно разнообразны, но при этом ограничиваются железосодержащими минералами (оксидами и сульфатами железа) и, возможно, силикогерманатами. Причем характер этих минеральных фаз указывает на полихронность формирования германиевого оруденения в месторожде- нии. С одной стороны, содержащие германий ярозит, гётит, гидрогётит с высокой долей вероятности сформировались в связи с образованием коры выветривания по грейзенизированным гранитам. Особенно отчетливо это видно на примере углей и углистых алевролитов, обрамляющих выступ, представленный реликтовой корой выветривания по грейзенизированным гранитам в центре месторождения. Германиеносные угли здесь вблизи контакта насыщены желе30-марганцевыми «корками», содержащими до 0,5 \% $\mathrm{Ge}, 2 \% \mathrm{~W}$ и 5,5 \% As. С другой стороны, в углях присутствуют силикатные пленки, содержащие до 0,5 \% $\mathrm{Ge}$ и сформировавшиеся по пириту. Пирит выполняет полости, заполняя трещинки в органическом веществе, образуя линзообразные выделения. Отчетливо видна его эпигенетичность по отношению к гелефицированному органическом веществу углей. Частично пириты подверглись коррозии. После этого по ним развивались силикатные пленки с аномально высоким содержанием германия. Формирование этих пленок очевидно эпигенетично по отношению к пириту. Причем такие пленки выявлены и вне связи с пириTOM.

Неоднозначное соотношение форм нахождения германия в металлоносных углях месторождения Спецугли подчеркивается и отсутствием значимой корреляции между содержанием германия в угле с зольностью. Отсутствие такой связи отмечают в своей работе и другие авторы [6]. Причины нарушения корреляционной связи могут быть связаны со значительной ролью аутигенных германийсодержащих минеральных фаз и аморфных силикатных пленок в общем балансе металла в германиеносных углях. При этом из всего массива полученных данных очевидно преобладание органических форм германия.

\section{Заключение}

Проведенные исследования показали, что в высокогерманиеносных углях месторождения Спецугли германий характеризуется разнообразными формами нахождения. Наряду с преобладающей органической формой нахождения $\mathrm{Ge}$ значительную роль играют минеральные фазы. Органические формы германия разнообразны и не ограничиваются комплексными гуматами. Значение минеральных фаз в концентрировании германия в высокогерманиеносных углях, вероятно, значительно выше, чем предполагалось ранее. В угольных пластах, особенно отчетливо вблизи коры выветривания по грейзенизированным гранитам, широко распространены различные германийсодержащие минеральные фазы микронной и нанометровой размерности. В углях встречаются алюмосиликатная (силикатная) форма германия, разнообразные железистые (гидрогётит, гётит, ярозит) и полиминеральные фазы. Алюмосиликатная (силикатная) фаза представлена пленкоподобными агрегатами, содержащими 0,15-0,4 \% германия. В железистых минеральных агрегатах содержится от 0,1 до 6,2 \% германия. Аномальные содержания Ge совместно c W и As установлены в железомарганцевых корках - продуктах выветривания грейзенизированных гранитов фундамен- 
та, сформировавшихся в условиях палеоболота. Выявленные минеральные фазы германия в углях месторождения Спецугли хорошо согласуются с общей геохимией этого элемента, обладающего сродством с $\mathrm{Fe}$ и $\mathrm{Si}$ и способного изоморфно входить в структуру их минералов.

Наличие вторичных германийсодержащих минеральных фаз в углях, развитых по диагенетическим минералам, позволяет предполагать, что формирование германиевой минерализации в месторождении может быть полихронным и не ограничивается торфяной стадией.

Для вольфрама характерна преимущественно органическая форма нахождения. Роль минеральных форм W в общем его балансе в углях месторождения

\section{СПИСОК ЛИТЕРАТУРЫ}

1. Середин В.В. Металлоносность углей: условия формирования и перспективы освоения // Угольная база России. Т. VI. - М.: Геоинформмарк, 2004. - С. 453-519.

2. Seredin V., Finkelman R. Metalliferous coals: a review of the main genetic and geochemical types // International Journal of Coal Geology. - 2008. - V. 76. - P. 253-289.

3. Вялов В.И., Олейникова Г.А., Наставкин А.В. Особенности распределения германия в углях Павловского месторождения // Химия твердого топлива. - 2020. - № 3. - С. 49-56.

4. Шпирт М.Я. Формы соединений микроэлементов и их превращения при переработке твердых горючих ископаемых // Химия твердого топлива. - 2004. - № 6. - С. 62-84.

5. Юдович Я.Э., Кетрис М.П. Германий в углях. - Сыктывкар: Коми НЦ УрО РАН, 2004. - 216 с

6. Формы нахождения германия в бурых углях германиеносного месторождения Приморья / А.С. Якушевич, С.Ю. Братская, В.В. Иванов, Н.В. Полякова, В.А. Авраменко // Геохимия. 2013. - № 5. - C. 453-461.

7. Редкие металлы в буроугольных месторождениях Приморья и их ресурсный потенциал / В.И. Вялов, А.И. Ларичев, Е.В. Кузеванова, А.Х. Богомолов, М.И. Гамов // Региональная геология и металлогения. - 2012. - № 51. - С. 96-105.

8. Костин Ю.П., Мейтов Е.С. К генезису месторождений высокогерманиеносных углей и критериям их поисков // Изв. АН СССР. Сер. геол. - 1972. - № I. - С. 112-119.

9. Павлюткин Б.И., Петренко Т.И., Чекрыжов И.Ю. Проблемы стратиграфии Павловского угольного поля (Приморье) // Тихоокеанская геология. -2005 . - № 6. - С. 59-76.

10. Седых А.К. Кайнозойские рифтогенные впадины Приморья (геологическое строение, минерагения и геодинамика углегенеза). - Владивосток: Дальнаука, 2008. - 248 с.

11. Кузеванова Е.М. Металлоносность углей кайнозойских буроугольных месторождений Приморья: дис. ... канд. геол.минерал. наук. - СПб., 2014. -133 с.

12. Формы нахождения редкоземельных элементов ( $\mathrm{La}, \mathrm{Ce}, \mathrm{Sm}$, $\mathrm{Eu}, \mathrm{Tb}, \mathrm{Yb}, \mathrm{Lu}$ ) в углях Северной Азии / С.И. Арбузов, Р.Б. Финкельман, С.С. Ильенок, С.Г. Маслов, А.М. Межибор, М.Г. Блохин // Химия твердого топлива. - 2019. - № 1. - С. 3-25.

13. Occurrence mode of selected elements in coal of the Ordos Basin / J. Wang, L. Xiao, P. Li, S. I. Arbuzov, S. Ding // Energy Exploration \& Exploitation. - 2019. - V. 37. - № 6. - P. 1680-1693.

14. Modes of occurrence of Rare earth elements in peat from Western Siberia / S.I. Arbuzov, S.G. Maslov, R.B. Finkelman, A.M. Mezhibor, S.S. Ilenok, M.G. Blokhin, E.V. Peregudina // Journal of Geochemical Exploration. - 2018. - V. 184. - P. 40-48.

15. Середин В.В. Аномальные концентрации элементов-примесей в месторождении германия «Спецугли» (Павловское буроугольное месторождение, Южное Приморье). Сообщение 1. Сурьма // Литология и полезные ископаемые. - 2003. - № 2. - С. 1-9.

16. ГОСТ 9517-94. Топливо твердое. Методы определения выхода гуминовых кислот. - М.: ИПК Изд-во стандартов, 1996. - 11 с.

17. ГОСТ 10969-91 (ИСО 975-85, ИСО 1017-85) Угли бурые и лигниты. Методы определения выхода толуольного экстракта
Спецугли незначительна. В изученных 9 пробах угля выявлено всего 1 зерно шеелита микронного размера. Вблизи коры выветривания вольфрам в углях встречается в качестве примеси также в железомарганцевых «корках». Этот вывод согласуется с результатами анализа распределения $\mathrm{W}$ по фракциям группового состава. После извлечения гумусовых кислот в щелочную вытяжку переходит в среднем $99 \%$ вольфрама. При этом в щелочной вытяжке около половины его связано с гуминовыми кислотами, а остальная часть - с низкомолекулярными органическими кислотами.

Исследование выполнено за счет гранта Российского научного фонда (проект №18-17-00004).

и содержания в нем растворимых в ацетоне веществ (смолистые вещества). - М.: Изд-во стандартов, 1992. - 11 с.

18. Enrichment of germanium and associated arsenic and tungsten in coal and roll-front uranium deposits / B. Etschmann, W. Liu, K. Li, S. Dai, F. Reith, D. Falconer, G. Kerr, D. Paterson, D. Howard, P. Kappen, J. Wykes, J. Brugger // Chemical Geology. - 2017. V. 463. - P. 29-49.

19. Petrology, mineralogy, and geochemistry of the Ge-rich coal from the Wulantuga Ge ore deposit, Inner Mongolia, China: new data and genetic implications / S. Dai, X. Wang, V.V. Seredin, J.C. Hower, C.R. Ward, J.M.K. O'Keefe, W. Huang, T. Li, X. Li, Hu. Liu, W. Xue, L. Zhao // International Journal of Coal Geology. - 2012. - V. 90-91. - P. 72-99.

20. Elemental and mineralogical anomalies in the coal-hosted Ge ore deposit of Lincang, Yunnan, southwestern China: key role of N2CO2-mixed hydrothermal solutions / S. Dai, P. Wang, C.R. Ward, Y. Tang, X. Song, J. Jiang, J.C. Hower, T. Li, V.V. Seredin, N.J. Wagner, Y. Jiang, X. Wang, J. Liu // Int. J. of Coal Geology. - 2015. - V. 152. - P. 19-46.

21. Yudovich Ya.E. Coal inclusions in sedimentary rocks: a geochemical phenomenon. A review // Int. J. Coal Geology. 2003. - V. 56. - № 3-4. - Р. 203-222.

22. Сендульская Т.И., Шпирт М.Я. О соосаждении микроколичеств германия с гидроокисью железа // Доклады АН СССР. 1960. - Т. 134. - № 5. - С. 1108-1110.

23. Юдович Я.Э., Кетрис М.П. Ценные элементы-примеси в углях. - Екатеринбург: УрО РАН, 2006. - 538 с.

24. Юровский А.З. Минеральные компоненты твердых горючих ископаемых. - М.: Недра, 1968. - 214 с.

25. Combustion and leaching behavior of elements in the Argonne Premium Coal Samples / R.B. Finkelman, C.A. Palmer, M.R. Krasnow, P.J. Aruscavage, G.A. Sellers., F.T. Dulong // Energy Fuels. - 1990. - V. 4. - № 6. - P. 755-766.

26. An evaluation of leaching to determine modes of occurrence of selected toxic elements in coal / C.A. Palmer, S.R. Krasnow, R.B. Finkelman, W.M. D'Angelo // J. Coal Qual. - 1993. V. 12. - № 4. - P. 135-141.

27. Середин В.В., Магазина Л.О. Минералогия и геохимия ископаемой древесины Павловского буроугольного месторождения (Приморье) // Литология и полезные ископаемые. 1999. - № 2. - С. 158-173.

28. Лаврик Н.А., Литвинова Н.М., Ван-Ван-Е А.П. Самородный вольфрам и другие микроминеральные фазы вольфрама в бурых углях и золе Ушумунского буроугольного месторождения и Сутарского проявления (Дальний Восток) // Вопросы геологии и комплексного освоения природных ресурсов восточной Азии: Третья Всерос. науч. конф.: сб. докладов в 2-х т. - Благовещенск: ИГиП ДВО РАН, 2014. - Т. 1. - С. 120-123.

29. Лаврик Н.А., Литвинова Н.М. Микроминеральная составляющая бурых углей и золы Ушумунского и Сутарского месторождений (юг Дальнего Востока) и перспективы использования // Вестник ЗабГУ. - 2015. - Т. 118. - № 3. - С. 38-47.

30. Mineralogy and geochemistry of vitrain lens with unique trace element content from the Vulche Pole coal deposit, Bulgaria / 
S.V. Vassilev, G.M. Eskenazy, M.P. Tarasov, V.I. Dimov // Geologica Balcanica. - 1995. - V. 25. - № 3-4. - P. 111-124.

31. Манская С.М., Дроздова Т.В. Геохимия органического вещества. - М.: Наука, 1964. - 315 с.

32. Germanium occurrence in Lincang superlarge deposit in Yunnan, China / H.P. Zhuang, J.L. Lu, J.M. Fu, J.Z. Liu, C.G. Ren, D.G. Zou // Sci. China D 41 (Suppl). - 1998. - P. 21-27.

33. Bekyarova E.E., Rouschev D.D. Forms of binding of germanium in solid fuels // Fuel. - 1971. - V. 50. - P. 272-279.

34. Electron probe microanalysis of major and trace elements in coals and their low-temperature ashes from the Wulantuga and Lincang
Ge ore deposits, China / Q. Wei, S. Dai, L. Lefticariu, G. Costin // Fuel. - 2018. - V. 215. - P. 1-12.

35. Geochemistry and mineralogy of the Cretaceous Wulantuga highgermanium coal deposit in Shengli coal field, Inner Mongolia, Northeastern China / X. Zhuang, X. Querol, A. Alastuey, R. Juan, F. Plana, A. Lopez-Soler, G. Du, V.V. Martynov // Int. J. of Coal Geology. - 2006. - V. 66. - P. 119-136.

36. Химия и технология редких и рассеянных элементов. Ч. 2 // под ред. К.А. Большакова. - М.: Высшая школа, 1976. - 311 с.

Поступила 15.10.2020 2.

\section{Информация об авторах}

Арбузов С.И., доктор геолого-минералогических наук, профессор отделения геологии Инженерной школы природных ресурсов Национального исследовательского Томского политехнического университета.

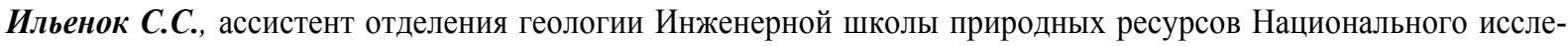
довательского Томского политехнического университета.

Чекрыљжв И.Ю., научный сотрудник, Дальневосточный геологический институт ДВО РАН. 
UDC 553.493:550.42

\title{
MODES OF OCCURRENCE OF GERMANIUM AND TUNGSTEN IN THE SPETSUGLI GERMANIUM ORE FIELD (RUSSIAN FAR EAST)
}

\author{
Sergey I. Arbuzov 1 , \\ siarbuzov@mail.ru
}

\author{
Sergey S. Ilenok ${ }^{1}$, \\ ilenokss@tpu.ru \\ Igor Yu. Chekryzhov², \\ chekr2004@mail.ru \\ 1 National Research Tomsk Polytechnic University, \\ 30, Lenin avenue, Tomsk, 634050, Russia. \\ 2 Far Eastern Geological Institute FEB RAS, \\ $159,100^{\text {th }}$ anniversary of Vladivostok avenue, Vladivostok, 690022, Russia.
}

The relevance of the research is conditioned by the need of the assessment of the modes of occurrence of germanium and other secondary trace elements in rare-metal coal deposits.

The main objective is to study the modes of occurrence of germanium and tungsten in metal-bearing coals of the Spetsugli deposit (Russian Far East).

Objects: coal and coal siltstones of the Ge-coal deposit.

Methods: correlation analysis, phase composition study of the brown coal, mass spectrometry with inductively coupled plasma, instrumental neutron activation analysis, scanning electron microscopy.

Results. Main modes of Ge and W occurrence were studied. High-germanium-bearing coals of the Spetsugli deposit are characterized by different modes of occurrence. Along with the prevailing organic mode of Ge occurrence, mineral phases play a significant part. The importance of the mineral modes of Ge occurrence in the high-germanium coals is probably much higher than it has been previously thought. Various micron and nanometer mineral phases of $\mathrm{Ge}$ are widespread in the coal seams, especially near the weathering crust along the greisenized granites. In coals, aluminosilicate (silicate) mode of $\mathrm{Ge}$, various ferrous (hydrogoethite, goethite, jarosite) and polymineral phases were met. The aluminosilicate (silicate) phase is represented by film-like congeries containing $0,15-0,4 \%$ of germanium. Ferrous mineral congeries contain from 0,1 to 6,2 \% of germanium. Anomalous Ge contents together with $W$ and As were found in ferromanganese crusts - weathering products of greisenized granite of the basement, formed in the paleo-bog conditions. The presence of the secondary mineral phases of germanium in the coals allows assuming that Ge mineralization formation in the deposit can be longer in time than it has been considered earlier and is not limited to the peat stage. The research conducted has shown that in the highly-germanium coals of the Spetsugli deposit along with the organic modes of $\mathrm{Ge}$ occurrence the mineral phases play a significant role. The organic modes of occurrence are diverse and are not limited to complex humates. Tungsten is mainly characterized by the organic mode of occurrence. The role of the $W$ mineral forms in its general balance in the coals of the Spetsugli deposit is insignificant. Only 1 grain of scheelite was found in the coals. Close to the weathering crust, tungsten in the coals was also found in the iron-manganese "crusts». It agrees with the results of the analysis of the W distribution coal phases. After the extraction of humus acids, $99 \%$ of tungsten on the average passes into the alkaline extract. In the alkaline extract, about half of it is associated with the humic acids, and the rest is associated with the low-molecular organic acids.

\section{Key words:}

Ge-coal deposit, coal, modes of occurrences, germanium, tungsten, organic association, micro-mineral forms.

The research was carried out under the support of the grant of the Russian Science Foundation (Project no. 18-17-00004).

\section{REFERENCES}

1. Seredin V.V. Metallonosnost ugley: usloviya formirovaniya i perspektivy osvoeniya [Metal content of coals: formation conditions and development prospects]. Ugolnaya baza Rossii [Coal base of Russia] T. VI. Moscow, Geoinformmark Publ., 2004. pp. 453-519.

2. Seredin V., Finkelman R. Metalliferous coals: a review of the main genetic and geochemical types. International Journal of Coal Geology, 2008, vol. 76, pp. 253-289.

3. Vyalov V.I., Oleynikova G.A., Nastavkin A.V. Features of the distribution of germanium in the coals of the Pavlovsky deposit. Solid Fuel Chemistry, 2020, no. 3, pp. 49-56. In Rus.

4. Shpirt M.Ya. Forms of compounds of trace elements and their transformation during the processing of solid fossil fuels. Solid Fuel Chemistry, 2004, vol. 38, no. 6, pp. 51-72.

5. Yudovich Ya.E., Ketris M.P. Germaniy v uglyakh [Germanium in coals]. Syktyvkar, Komi NC UrO RAS Publ., 2004. 216 p.

6. Yakushevich A.S., Bratskaya S.Y., Ivanov V.V., Polyakova N.V., Avramenko V.A. Germanium speciation in lignite from a germa- nium-bearing deposit in Primorye. Geochemistry International, 2013, vol. 51, no. 5, pp. 405-412. In Rus.

7. Vyalov V.I., Larichev A.I., Kuzevanova E.V., Bogomolov A.H., Gamov M.I. Redkie metally v burougolnykh mestorozhdeniyakh Primorya i ikh resursniy potentsial [Rare metals in lignite deposits of Primorye and their resource potential]. Regionalnaya geologiya i metallogeniya, 2012, no. 51, pp. 96-105.

8. Kostin Yu.P., Meytov E.S. K genezisu mestorozhdeniy vysokogermanienosnykh ugley i kriteriyam ikh poiskov [On the genesis of high-Germaniferous coal deposits and criteria for their prospecting]. Izv. AN SSSR. Ser. geol, 1972, no. I, pp. 112-119.

9. Pavlyutkin B.I., Petrenko T.I., Chekryzhov I.Yu. Problemy stratigrafii Pavlovskogo ugolnogo polya (Primore) [Problems of stratigraphy of the Pavlovskoe coal field (Primorye)]. Tikhookeanskaya geologiya, 2005, no. 6, pp. 59-76.

10. Sedykh A.K. Kaynozoyskie riftogennye vpadiny Primorya (geologicheskoe stroenie, minerageniya $i$ geodinamika uglegeneza) [Cenozoic riftogenic depressions in Primorye (geological structure, 
minerageny and geodynamics of coal genesis)]. Vladivostok, Dalnauka Publ., 2008. 248 p.

11. Kuzevanova E.M. Metallonosnost ugley kaynozoyskikh burougolnykh mestorozhdeniy Primorya. Diss. Kand. nauk [Metal content of coals from Cenozoic brown coal deposits in Primorye. Cand. Diss.]. St.-Petersburg, 2014. 133 p.

12. Arbuzov S.I., Finkelman R.B., Il'enok S.S., Maslov S.G., Mezhibor A.M., Blokhin M.G. Modes of occurrence of rare-earth elements $(\mathrm{La}, \mathrm{Ce}, \mathrm{Sm}, \mathrm{Eu}, \mathrm{Tb}, \mathrm{Yb}, \mathrm{Lu})$ in coals of Northern Asia. Solid Fuel Chemistry, 2019, vol. 53, no. 1, pp. 1-21. In Rus.

13. Wang J., Xiao L., Li P., Arbuzov S. I., Ding S.. Occurrence mode of selected elements in coal of the Ordos Basin. Energy Exploration \& Exploitation, 2019, vol. 37, no. 6, pp. 1680-1693.

14. Arbuzov S.I., Maslov S.G., Finkelman R.B., Mezhibor A.M., Ilenok S.S., Blokhin M.G., Peregudina E.V. Modes of occurrence of Rare earth elements in peat from Western Siberia. Journal of Geochemical Exploration, 2018, vol. 184, pp. 40-48.

15. Seredin V.V. Anomalnye kontsentratsii elementov-primesey v mestorozhdenii germaniya «Spetsugli» (Pavlovskoe burougolnoe mestorozhdenie, Yuzhnoe Primorye). Soobshcheniye 1. Surma [Anomalous trace elements contents in the Spetsugli germanium deposit (Pavlovsk brown coal deposit) Southern Primorye: Communication 1. Stibium]. Litologiya i poleznye iskopaemye, 2003, no. 2, pp. 1-9

16. GOST 9517-94. Toplivo tverdoe. Metody opredeleniya vykhoda guminovykh kislot [State Standart 9517-94. The solid fuel. Methods for determining the yield of humic acids]. Moscow, IPK Izdatelstvo standartov, $1996.11 \mathrm{p}$.

17. GOST 10969-91 (ISO 975-85, ISO 1017-85). Ugli burye i lignity. Metody opredeleniya vykhoda toluolnogo ekstrakta i soderzhaniya $v$ nem rastvorimykh $v$ atsetone veshchestv (smolistye veshchestva) [State Standart 10969-91 (ISO 975-85, ISO 1017-85). Brown coals and lignites. Methods for determining the yield of toluene extract and the content of acetone-soluble substances in it (resinous substances)]. Moscow, Izdatelstvo standartov, 1992.11 p

18. Etschmann B., Liu W., Li K., Dai S., Reith F., Falconer D., Kerr G. Paterson D., Howard D., Kappen P., Wykes J., Brugger J. Enrichment of germanium and associated arsenic and tungsten in coal and roll-front uranium deposits. Chemical Geology, 2017, vol. 463, pp. 29-49.

19. Dai S., Wang X., Seredin V.V., Hower J.C., Ward C.R., O'Keefe J.M.K., Huang W., Li T., Li X., Liu Hu., Xue W., Zhao L. Petrology, mineralogy, and geochemistry of the Ge-rich coal from the Wulantuga Ge ore deposit, Inner Mongolia, China: new data and genetic implications. International Journal of Coal Geology, 2012, vol. 90-91, pp. 72-99.

20. Dai S., Wang P., Ward C.R., Tang Y., Song X., Jiang J., Hower J.C., Li T., Seredin V.V., Wagner N.J., Jiang Y., Wang X., Liu J. Elemental and mineralogical anomalies in the coal-hosted Ge ore deposit of Lincang, Yunnan, southwestern China: key role of $\mathrm{N}_{2-}$ $\mathrm{CO}_{2}$-mixed hydrothermal solutions. Int. J. of Coal Geology, 2015, vol. 152, pp. 19-46.

21. Yudovich Ya.E. Coal inclusions in sedimentary rocks: a geochemical phenomenon. A review. Int. J. Coal Geology, 2003, vol. 56, no. 3-4, pp. 203-222.

22. Sendulskaya T.I., Shpirt M.Ya. O soosazhdenii mikrokolichestv germaniya s gidrookisyu zheleza [On coprecipitation of germanium trace amounts with iron hydroxide]. Doklady AN SSSR, 1960, vol. 134, no. 5. pp. 1108-1110.

23. Yudovich Ya.E., Ketris M.P. Tsennye elementy-primesi v uglyakh [Valuable impurity elements in coals]. Ekaterinburg, UrO RAN Publ., 2006. 538 p.
24. Yurovskiy A.Z. Mineralnye komponenty tverdykh goryuchikh iskopaemykh [Mineral components of solid fossil fuels]. Moscow, Nedra Publ., 1968. 214 p.

25. Finkelman R.B., Palmer C.A., Krasnow M.R., Aruscavage P.J., Sellers G.A., Dulong F.T. Combustion and leaching behavior of elements in the Argonne Premium Coal Samples. Energy Fuels, 1990, vol. 4, no. 6, pp. 755-766.

26. Palmer C.A., Krasnow S.R., Finkelman R.B., D’Angelo W.M. An evaluation of leaching to determine modes of occurrence of selected toxic elements in coal. J. Coal Qual., 1993, vol. 12, no. 4, pp. $135-141$.

27. Seredin V.V., Magazina L.O. Mineralogiya i geokhimiya iskopaemoy drevesiny Pavlovskogo burougolnogo mestorozhdeniya (Primore) [Mineralogy and geochemistry of fossil wood of the Pavlovskoe lignite deposit (Primorye)]. Litologiya i poleznye iskopaemye, 1999, no. 2, pp. 158-173.

28. Lavrik N.A., Litvinova N.M., Van-Van-E A.P. Samorodny volfram i drugie mikromineralnye fazy volframa $\mathrm{v}$ burykh uglyakh $\mathrm{i}$ zole Ushumunskogo burougonogo mestorozhdeniya i Cutarskogo proyavleniya (Dalniy Vostok) [Native tungsten and other micromineral phases of tungsten in lignite and ash of the Ushumun lignite deposit and the Sutar occurrence (Far East)]. Voprosy geologii $i$ kompleksnogo osvoeniya prirodnykh resursov vostochnoy Azii: Tretya Vserossiyskaya nauchnaya konferentsiya. Sbornik dokladov [Issues of geology and integrated development of natural resources in East Asia. Proc. of the third All-Russian scientific conference]. Blagoveshchensk, IGiP DVO RAN Publ., 2014. Vol. 1, pp. 120-123.

29. Lavrik N.A., Litvinova N.M. Mikromineralnaya sostavlyayushchaya burykh ugley i zoly Ushumunskogo i Sutarskogo mestorozhdeniy (yug Dalnego Vostoka) i perspektivy ispolzovaniya [Micro-mineral component of lignites and ash from the Ushumunskoye and Sutarskoye deposits (south of the Far East) and prospects for use]. Vestnik ZabGU, 2015, vol. 118, no. 3, pp. 38-47.

30. Vassilev S.V., Eskenazy G.M., Tarasov M.P., Dimov V.I. Mineralogy and geochemistry of vitrain lens with unique trace element content from the Vulche Pole coal deposit, Bulgaria. Geologica Balcanica, 1995, vol. 25, no. 3-4, pp. 111-124.

31. Manskaya S.M., Drozdova T.V. Geokhimiya organicheskogo veshchestva [Geochemistry of organic matter]. Moscow, Nauka Publ., 1964. $315 \mathrm{p}$

32. Zhuang H.P., Lu J.L., Fu J.M., Liu J.Z., Ren C.G., Zou D.G. Germanium occurrence in Lincang superlarge deposit in Yunnan, China. Sci. China D 41 (Suppl), 1998, pp. 21-27.

33. Bekyarova E.E., Rouschev D.D. Forms of binding of germanium in solid fuels. Fuel, 1971, vol. 50, pp. 272-279.

34. Wei Q., Dai S., Lefticariu L., Costin G. Electron probe microanalysis of major and trace elements in coals and their low-temperature ashes from the Wulantuga and Lincang Ge ore deposits, China. Fuel, 2018, vol. 215, pp. 1-12.

35. Zhuang X., Querol X., Alastuey A., Juan R., Plana F., LopezSoler A., Du G., Martynov V.V. Geochemistry and mineralogy of the Cretaceous Wulantuga high-germanium coal deposit in Shengli coal field, Inner Mongolia, Northeastern China. Int. J. of Coal Geology, 2006, vol. 66, pp. 119-136.

36. Khimiya i tekhnologiya redkikh i rasseyannykh elementov [Chemistry and technology of rare and trace elements]. Ed. by K.A. Bolshakova. Moscow, Vysshaya shkola Publ., 1976. P. 2, 311 p.

Received: 15 October 2020.

\section{Information about the authors}

Sergey I. Arbuzov, Dr. Sc., professor, National Research Tomsk Polytechnic University.

Sergey S. Ilenok, assistant, National Research Tomsk Polytechnic University.

Igor Yu. Chekryzhov, researcher, Far Eastern Geological Institute FEB RAS. 